\title{
Sales Efficiency in Life Insurance: The Drivers for Growth in the German Market
}

\author{
Jonas Lorson and Joël Wagner \\ Institute of Insurance Economics, University of St. Gallen, Tannenstrasse 19, St. Gallen 9000, Switzerland.
}

German life insurers are facing consolidation tendencies as the major players increase their market share. As a result, insurance companies are being forced to grow to ensure future prosperity. In the past, the industry has shown that growth can be achieved while maintaining profitability. The central question of our research is to detect factors for the generation of new business. In order to determine what drives sales - and thus growth — in the German life insurance industry, we apply different multi-linear regression models. We use panel data from 1998 to 2011 with characteristics of German life insurers and mostly full market coverage. In our modelling, we distinguish between sales success on the business unit level of life insurance and on the level of specific life products. The sales success drivers for pension insurance as well as term life insurance are analysed. By doing so, we determine different significant drivers for sales success, which include the total return granted to policyholders, commissions paid to sales partners, the solvency of the insurer, company (financial) rating and firm size.

The Geneva Papers (2014) 39, 493-524. doi:10.1057/gpp.2013.35

Keywords: life insurance; new business growth; profitability

Article submitted 16 April 2013; accepted 14 November 2013; published online July 2014

\section{Introduction}

Because life expectancy for people in the developed world has increased significantly over the last few decades, the need for additional old-age provisioning is becoming more and more important. ${ }^{1}$ Individuals' awareness that the state pension system might not be sufficient to maintain their current living standard in the future is increasing. ${ }^{2}$ In order to meet this challenge, private investments in retirement solutions can serve as an additional source of income later on in life. The literature provides several studies that analyse the drivers of life insurance demand in several countries. ${ }^{3}$ Overall, alternative investment opportunities, such as stock market returns, and the national economic situation through, for example, inflation rates, may strongly influence customers' purchase behaviour. However, we have seen fewer attempts so far to explain how demand for life insurance products is directed towards specific life insurance companies, or-framed differently—what enables some life insurers to capture a larger market share of the life insurance business than their competitors.

\footnotetext{
${ }^{1}$ Bonin (2009).

${ }^{2}$ See, for example, Handelsblatt (2011) and Wirtschaftswoche (2007b).

${ }^{3}$ See, for example, Browne and Kim (1993), Chen et al. (2001), and Li et al. (2007).
} 
With a total volume of 6.3 million new life insurance contracts in Germany in 2011 (GDV, Table 27) ${ }^{4}$ and 81.3 million inhabitants, ${ }^{5}$ almost one in 13 people buys a life insurance contract each year. This highlights the importance of the life insurance market and its products for the financial protection of whole generations. Customers oftentimes see life insurance products as very homogeneous ${ }^{6}$ and thus the question arises, what drives customers to choose a specific insurance provider?

In this paper, we analyse the impact of different firm-specific parameters on the overall sales success of life insurance in general, and of specific products in particular. In our analysis, we interpret an insurance company's yearly sales success as the proportion of new business premium volume to total premium volume in a given year. For new business, volume is calculated on the basis of the annual premium equivalent. The latter consists of the total value of regular (or periodic) premium payments in the year under review plus 10 per cent of the single premiums collected in the period. In our model, insurance companies are parameterised by sets of independent variables of different types. Among the parameters, we include accounting figures such as size, customer-oriented drivers such as customer satisfaction and brand awareness, and performance figures such as the annual return rates for policyholders. By doing so, we build on and extend the work of Cottin et al. ${ }^{7}$ and Eling and Kiesenbauer, ${ }^{8}$ where the latter is closest to our study. The authors used regression models to detect the main drivers of new business in the life insurance industry in the German market. We also make use of multiple linear regression models to determine essential drivers of new business generation. We use panel data covering a time period of 14 years, from 1998 to 2011, including data from about 100 firms (depending on the year) operating in the market. The empirical basis on which we conduct our analysis, corresponds to a set of 895 firm-years with complete data (vs 550 firm-years in Eling and Kiesenbauer), ${ }^{8}$ or, in other words, to companies which represent more than 90 per cent of the German life insurance market in terms of premiums in each year. The contribution of our paper to the literature is threefold: First, we examine the relationship between growth and profitability in the German life insurance market. Second, we adapt the approach of Eling and Kiesenbauer ${ }^{8}$ to a newer and broader data sample, including additional explanatory variables to the model. In this connection, we also focus on brand strength and customer satisfaction. Third, our work addresses the level of specific life products individually and analyses the growth drivers in pension insurance and term life insurance.

The remainder of this paper is organised as follows. The next section studies growth and profitability issues and provides an insight into the German life insurance market. Furthermore, a literature overview is presented. The subsequent section states our research hypotheses. The model framework and the panel data used are described in the latter section. In the penultimate section, the outcomes of our analysis are presented and discussed. While the section "Overall growth drivers in life insurance" studies the overall relationship of life insurers characteristics and their success in generating new life insurance business,

\footnotetext{
${ }^{4}$ GDV (2012).

5 Statistisches Bundesamt (2012).

${ }^{6}$ See, for example, Brown and Goolsbee (2002) and Dwyer et al. (2000).

${ }^{7}$ Cottin et al. (2007).

${ }^{8}$ Eling and Kiesenbauer (2012).
} 
the section "Product-specific growth drivers" focuses on two single life insurance products. Finally, the last section summarises the results and concludes.

\section{Perspectives on growth in life insurance}

The aim of the following is to introduce our research topic by providing insights into the life insurance market in Germany. The section "Growth and profitability in the German life insurance market" describes why it is of interest to analyse the drivers of new business growth in the current market situation. The section "Literature review" gives an overview of the existing literature on growth determinants. Insurance-specific studies are discussed as well as research from other financial services areas, such as fund investments. We include the latter due to their similarity to certain life insurance products.

\section{Growth and profitability in the German life insurance market}

In 1998, 119 life insurers operated in the German life insurance market. More than a decade later, the number of active firms decreased to 94 in 2011 (GDV, Table 2). ${ }^{4}$ This corresponds to a decline of 21 per cent. New regulatory requirements, especially concerning solvency capital and risk management of insurance firms, as well as inorganic growth through acquisition, mainly by public insurers, can explain this trend. ${ }^{9}$ After a phase of deregulation in the $1990 \mathrm{~s},{ }^{10}$ the regulator has increased his intervention over the last decade. Following an adaptation of the (yet existing) solvency rules in Germany at the beginning of the 2000s, ${ }^{11}$ the European Commission is currently planning the introduction of the new regulatory standard Solvency II. ${ }^{12}$ The phenomenon of decreasing firm numbers is accompanied by another trend which concerns the concentration of market shares among a few firms. In 2011, the ten largest companies represent 55 per cent of the life insurance premiums whereas the remaining 45 per cent are shared by 84 companies. Figure 1 shows the development of market share in terms of premium volume of the largest insurance companies for the years 1998-2011. ${ }^{13}$

The figures indicate that a concentration has occurred in the German life insurance industry. The five largest insurers have been able to increase their market share by 8 percentage points, from 31 per cent in 1998 to 39 per cent in 2011. The ten largest insurers together control more than half of the gross written premiums in the industry. When taking a closer look at the ten largest firms, an analysis shows that the composition of this group has been very stable over time. Very few changes have occurred: The same companies that led the market in terms of size in 1998 are still the largest ones today. Furthermore, they have been able to

\footnotetext{
${ }^{9}$ See, for example, Nektarios (2010), p. 453.

${ }^{10}$ See, for example, Klumpes and Schuermann (2011), and Berry-Stölzle and Born (2012).

${ }^{11}$ European Commission (2002), currently referred to as Solvency I.

12 European Commission (2009).

${ }^{13}$ Even if, from an economic point of view, groups of insurers are the relevant actors, many of them encompassing several life insurance companies, we conduct our analysis on a legal entity basis. In fact, our central research question concerns the drivers for growth and explicitly considers the customer perspective. Hereby, the different single entities with their own brand and distribution channels are of foremost importance for the customers' perception of an insurance company-and not the group view.
} 
496

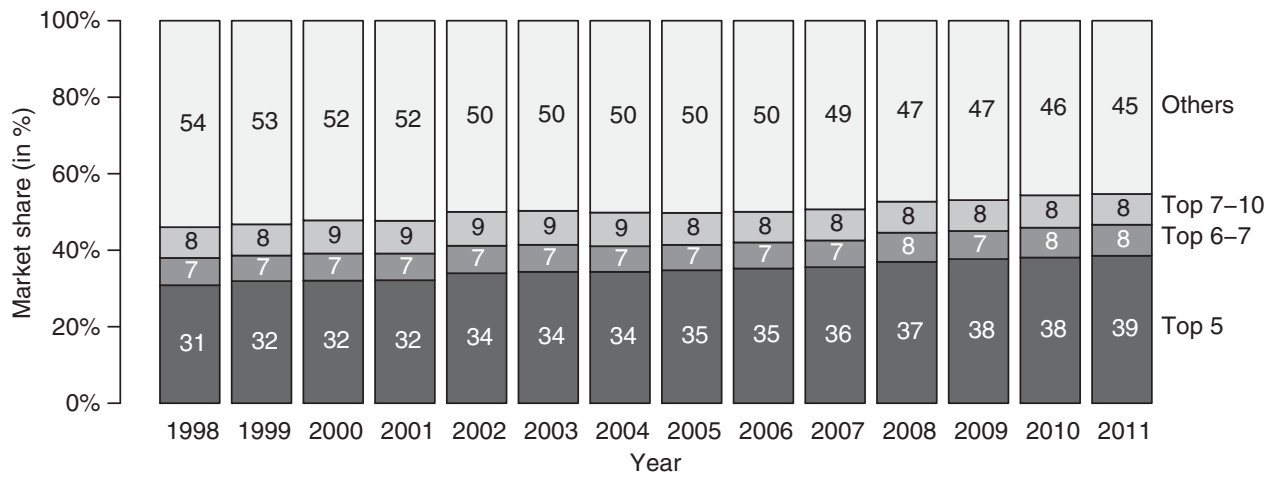

Figure 1. Development of market share for the years 1998-2011 in the German life insurance market.

Note: Market share is calculated as company life premium volume divided by total market life insurance premiums. The clusters are defined as follows: "Top 5" groups the five largest companies in the respective year, "Top 6-7" the sixth and seventh largest firms, and so on. Under "Others", we account for all companies which are not among the ten largest firms. The underlying premium data are collated on the basis of gross written premium figures included in annual reports.

increase their role in the market. If one assumes, on the basis of this historical observation and making a simple extrapolation, that this trend will continue into the future, more concentration to the detriment of small life insurers will be seen. ${ }^{14}$

When it comes to the strategic positioning of insurers, different goals have to be considered. Typically, strategic actions by insurance firms have to be in line with (at least) three oftentimes contradictory targets, that is, growth, profitability and safety. Although the first two targets are typically the focus of the owners of or investors in the firm, the safety level is monitored by the regulatory authorities for the protection of customers (see, for example, European Commission, ${ }^{12}$ Sect. 4, Art. 101). From a business development perspective, companies that pursue growth strategies without a sound risk assessment may run into problems in the long run, for example, due to wrong product developments or disadvantageous customer selection criteria. In order to grow their business, managers might also lose sight of profitability if they focus more on growth than on sound underwriting. Furthermore, most insurance companies operate on significantly higher safety levels than the minimum level required by supervisory authorities, and risk management is a major strategic variable for insurance firms. If a company has determined its target safety level, insurance managers can influence growth and profitability within the imposed solvency limits. Even if, similar to the situation found in many other industries, growth is essential for firms if they want to play a vital role in the future, managers should not lose sight of profitability. If growth is only achieved at the expense of prosperity, the impact on the firm's value can be devastating. ${ }^{15}$

\footnotetext{
${ }^{14}$ In order to derive a more differentiated view on the historic trends, structural changes in the market environment would need to be considered, namely, for example, the tax reforms, the implementation of Riester pension schemes, the increased volatility of financial markets and the low interest-rate environment. Also note that figures from additional market players, for example, the European Economic Area, are not included in the statistic used in Figure 1.

${ }^{15}$ See, for example, Varaiya et al. (1987) and Longenecker et al. (1999).
} 

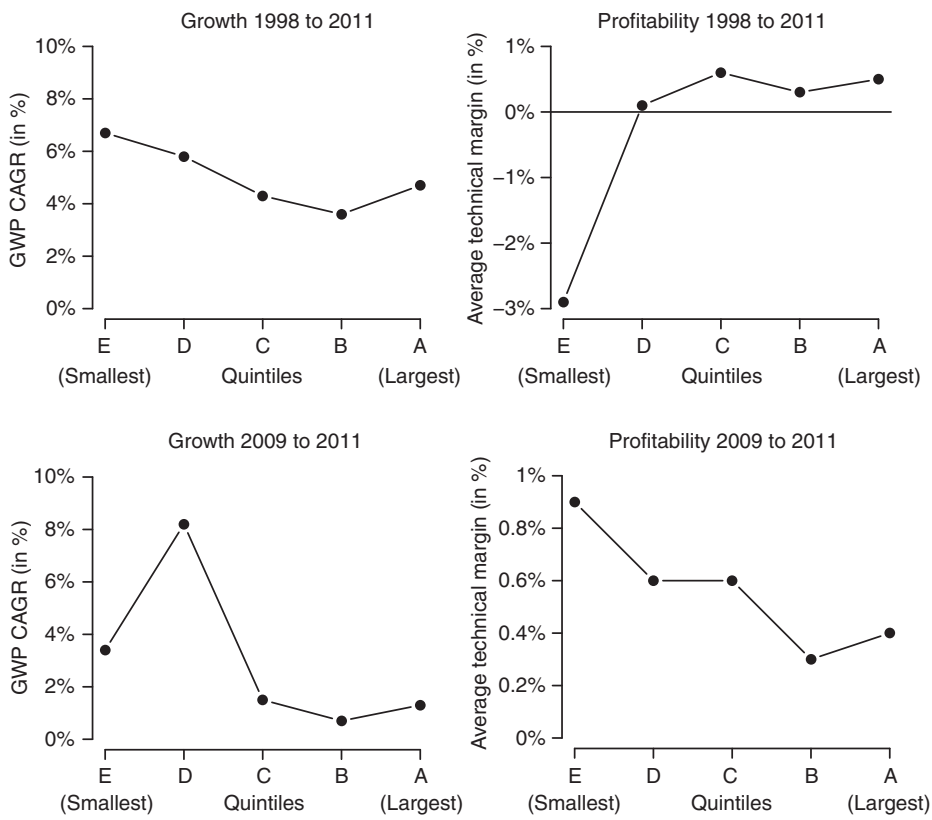

Figure 2. Growth and profitability in the German life insurance industry from 1998 to 2011.

Note: The graphs allow a side-by-side comparison of growth and profitability in the German life insurance market for the time period from 1998 to 2011 split into the two periods running from 1998 to 2008 (pre-crisis) and 2009 to 2011 according to firm size-based quintiles. Quintile A represents the largest firms while Quintile E is comprised of the smallest companies in terms of gross written premiums (GWP). Quintile growth is defined as the compounded annual growth rate (CAGR) of the quintile's total GWP for the respective time period; quintile profitability is defined as the average quintile's technical margin.

In order to evaluate this issue, we analyse the impact of size on growth and profitability in the German life insurance sector. Therefore, we group life insurance companies into quintiles according to their premium volume (annual gross written premiums). The largest companies are grouped in Quintile A and the smallest are in Quintile E. For each of the players, we calculate average growth and average profitability. When it comes to growth, we base our analysis on the compounded annual growth rate (CAGR) of gross written premiums (summed up in each quintile). For the sake of our analysis, we define a quintile's profitability as the technical margin. The technical margin is obtained by dividing the companies' operating profit by their technical reserves (both for traditional and fund business). Note that with that definition profitability is based on accounting figures or book values, ignoring any hidden reserves or burdens.

In the following, we consider the time period from 1998 to 2011. Over this time horizon, the gross written premium CAGR is contrasted with the average technical margin (average over the time period). We separately consider the time period before the last financial crisis (1998-2008) and the time period beginning after the start of the last financial crisis (2009-2011). The results are illustrated in the graphs in Figure 2.

Three main effects can be observed in this analysis. First, on the basis of the data from 1998 to 2008, small companies seem to achieve higher growth rates compared with 
companies in all other quintiles; such rates can be more easily achieved by small firms than by larger firms due to the smaller premium base (relative growth over a smaller denominator). However, the figures indicate that this growth is realised at the expense of profitability. The smallest players on average have, for the entire period under observation, a technical margin of -2.9 per cent. This may be partly explained by the fact that these smallest firms include newly established life insurers and entities set up by larger groups to expand specific market segments. Losses or small profits are usually expected, since their first aim is growth and acceptance in the market. New business typically goes along with high commission payments which lower the profitability. This is why small firms with high growth rates automatically suffer a lower profitability than big firms that can more easily offset the commission effect. However, after the start of the last financial crisis, during the time period from 2009 to 2011, the picture changes. Forfeiting their high growth rates and now only growing at a CAGR of 3.3 per cent, the smallest players have been able to regain profitability. This may be due to significantly lower acquisition costs, in particular in relative terms when comparing them with larger companies. Another reason may also be that the crisis was hardly a time for new market entries or expansion into new market segments, which enabled the yet existing small players to strengthen their position. In that time period, they are even the most profitable companies within the comparison, with an average technical margin of 0.9 per cent. Second, mid-sized insurers (especially the group of the second largest companies in Quintile B) show a weak positioning when it comes to growth. Outperformed by the smallest players as well as the biggest ones, it seems that they might become subjected to the classic "stuck-in-the-middle" phenomenon ${ }^{16}$ when addressing premium growth. This moderate development in terms of growth is accompanied by a moderate profitability as well. Finally, the largest firms (Quintile A) show in all panels solid—but not outstanding_-growth rates while keeping profitability levels at a satisfying level. The analysed figures indicate that profitable growth is possible in the industry.

In the sequel and core part of this paper, we will focus on how this growth can be achieved. Therefore, starting in the section "Model framework and data set", we empirically analyse the drivers of sales success in the German life insurance market.

\section{Literature review}

As mentioned before, the existing literature covers several examinations of what drives life insurance demand. In one of the earliest studies, Mantis and Farmer ${ }^{17}$ use publicly available data such as the number of births, population development and the number of marriages to forecast life insurance demand with a multiple linear regression. Later Campbell ${ }^{18}$ argues from the perspective of uncertainty of household income due to the death of the wage earner and the need to "hedge" against this uncertainty with life insurance. Adapting the former model, Lewis ${ }^{19}$ introduces the risk aversion and utility of beneficiaries instead of wage earners as the drivers of life insurance demand. Browne and $\mathrm{Kim}^{20}$ leave the personal or

\footnotetext{
${ }^{16}$ Porter (1985).

${ }^{17}$ Mantis and Farmer (1968).

${ }^{18}$ Campbell (1980).

${ }^{19}$ Lewis (1989).

${ }^{20}$ Browne and Kim (1993).
} 
family level and analyse the impact of more general drivers on life insurance demand. They identify, for example, national income, government spending on social security and inflation as determinants of life insurance consumption. Chen $e t a l .{ }^{21}$ apply cohort analysis to life insurance demand in the United States. One of their conclusions is that the baby boomer generation has a lower life insurance demand than earlier generations. Li et al $^{22}$ analyse life insurance demand in OECD countries and find a positive relationship between income (and income increases) and life insurance demand.

However, fewer analyses try to explain how this demand is distributed among specific insurance firms, that is, what enables a given company to outgrow its competitors in Germany. Some studies in the field of life insurance address this issue. Tekülve ${ }^{23}$ examines the years 2003 and 2004 with respect to a potential relationship between surplus participation and new business. The impact is analysed using visual scatter plot analysis and Pearson's correlation coefficients. However, further significance tests or the inclusion of additional value drivers are missing. The results of the analysis indicate a positive relationship between the volume of new business and surplus participation. These results are confirmed both in the overall market as well as for subsamples, for example, with respect to legal form or the age of the company. Cottin $e t$ al. ${ }^{7}$ analyse the impact of surplus participation on new business and lapse figures. In their study, they use total return figures including the guarantee rate as surplus participation, but they adjust these numbers for market rates and utilise companyspecific performance spreads. The study covers the time period from 1995 to 2004. The authors come to the conclusion that surplus participation has no impact on the sales success of a company in terms of new business volume. However, it should be stated that the authors elaborate critically on their own findings. They are aware that a univariate approach might not incorporate all effects and that further drivers of new business, such as acquisition costs or ratings, should be included in the analysis. Eling and Kiesenbauer, ${ }^{8}$ most closely to our study, analyse the impact of different drivers on premium growth in light of market discipline. The authors find a positive relationship between the amount of surplus participation and the growth of new business for German life insurers. In addition, their results show empirical proof for a negative relationship between the surplus participation and the amount of lapses an insurer suffers. Based on a data set of 11 years, from 1998 to 2008, the authors introduce, in a multivariate regression model, further parameters as potential drivers of sales success besides surplus participation. Additional variables include, among others, company ratings and solvency measures. Some of these will also be considered in our analysis (see the section "Model framework and data set"). The findings of Eling and Kiesenbauer ${ }^{8}$ seem at a first glance contradictory to those of Cottin et al. ${ }^{7}$ However, these contradictory results can be explained by some issues inherent in the approach of Cottin et al..$^{7}$ First, a univariate linear regression model is used. Second, the modelling approach differs in the two studies when it comes to the definition of the participation rate. And third, the authors conduct different significance tests. However, all studies point out the importance of financial performance for sales success.

${ }^{21}$ Chen et al. (2001).

${ }^{22} \mathrm{Li}$ et al. (2007).

${ }^{23}$ Tekülve (2007). 
In a related research stream, customer purchase decisions and financial performance are often covered with respect to mutual funds. Sirri and Tufano, ${ }^{24}$ show, through an empirical study, that consumers, in their choice of investment, rely heavily on the past performance of the fund. This finding is supported by several other researchers: Choi et al. ${ }^{25}$ state that in the purchase decisions, individuals emphasise the fund's annualised returns since issue, and neglect other, more future-oriented and thus maybe more helpful purchase indicators. With his research, Wilcox ${ }^{26}$ also supports the role of historic performance in consumers' investment decisions. This clear focus on past performance is not diminished by conditioned information and explanations that are provided in special information prospectuses. ${ }^{27}$ One can argue that these theoretical findings can also be transferred to some extent to life insurance. ${ }^{28}$ When it comes, for example, to annuity products, the policy can be split into two parts: a savings period, or accumulation phase, of capital when the policyholder pays the contributions, and a redemption period, or decumulation phase, when he or she receives the annuity payments. Since policyholders can also close an annuity contract with a single premium payment and immediately begin the decumulation phase, the accumulation-or buildup of capital stock — can also occur as part of a savings contract with a mutual fund.

\section{Development of research hypotheses}

As mentioned before, our aim is to measure new business $(N B)$ as the share of new business annual premium equivalent (APE) in the total gross written premiums of the respective fiscal year. By only taking single premiums with 10 per cent into account, the APE figures smooth disturbances of large one-time effects in the P\&L of a life insurer. By using this approach, we also avoid the bias that might result from the size of the company, as small companies might realise higher growth rates than larger companies due to their smaller starting base. By focusing on relative new business values, we make companies comparable without having to bear their size in mind.

In the following, we consider distinct variables that are relevant to insurance distribution. This approach is closest to the work of Eling and Kiesenbauer. ${ }^{8}$ We define each parameter and formulate a hypothesis on the impact of the parameter on new business. In the section "Model framework and data set", we will then use the parameters as independent variables in the formulation of several regression models in order to empirically test the hypotheses.

\section{Total return (RE)}

First, we consider the investment performance of the insurer and the total return to policyholders. When it comes to the return that policyholders receive in the German life

${ }^{24}$ Sirri and Tufano (1998).

25 Choi et al. (2010).

${ }^{26}$ Wilcox (2003).

${ }^{27}$ Kozup et al. (2008).

${ }^{28}$ There are substantial differences between mutual funds and life insurance products with regard to, for example, the guarantees granted by life insurers and the customers' motives for taking out an insurance contract vs a fund investment. However, depending on the type of the life insurance contract and the additional returns on the investment that are possible, several links can be considered and the decision for a specific insurance provider is not only safety-oriented but also return-oriented. 
insurance market, a few unique features have to be kept in mind. The return guarantees insurers grant their policyholders are subject to regulatory constraints. The guaranteed interest may not be higher than the maximum interest rate guarantee defined by the regulator ("Höchstrechnungszins"). Following European Union directives, this threshold may not be higher than 60 per cent of the historic return on government bonds. ${ }^{29}$ As a consequence, this maximum interest guarantee is regularly updated. As of 1 January 2012, the maximum guarantee for new life contracts has been reduced from 2.25 to 1.75 per cent. ${ }^{30}$ Old contracts are not affected and may still have higher guaranteed rates. Usually, insurers keep their guarantees at the maximum value allowed.

Insurers have other means available for paying their customers more than the guarantee rate. Under German law, a company must pass on at least 90 per cent of the proceeds from investment income to policyholders. ${ }^{31}$ At least 75 per cent of the risk (or underwriting) results and at least 50 per cent of the cost results must be paid to policyholders. Negative results must be retained by the insurer. However, the insurer is free to abstain from its share and can increase the policyholder's participation in all three categories up to 100 per cent.

In our analysis, we consider total return rates for policyholders, that is, including the maximum guarantee rate as well as the surplus participation component. This total return rate is usually declared yearly during the first quarter of each year. Eling and Kiesenbauer ${ }^{8}$ point out that surplus participation is considered to have a significant impact on the ability to underwrite new business and refer to Zimmermann ${ }^{32}$ and Milbrodt and Helbig. ${ }^{33}$ Based on these studies and our discussion in the section "Literature review", we state our first hypothesis:

H1: Higher total returns for policyholders generate higher sales.

\section{Acquisition costs (AC)}

In our opinion, a company's acquisition costs for pushing new life business are another important parameter. For example, Fiegenbaum and Thomas ${ }^{34}$ analyse the impact of firms' expense ratios on their strategic positioning. We will focus only on the acquisition costs as a part of the total expenses (omitting, for example, administration and overhead costs). It can be expected that the higher the acquisition costs per premium are, the more successful the insurer will be in promoting sales through its salesforce and underwriting new business. This effect might look contradictory at first sight, as higher costs typically do not go along with the efficiency of a company; however, higher acquisition costs per premium (acquisition costs ratio) in the balance sheet represent higher commissions paid to the sales agents or brokers. Thus, they may tend to be more motivated to sell life insurance products and increase the new business volume of the insurer. Hence, we formulate our second hypothesis as follows:

H2: Higher acquisition cost levels yield higher sales volumes.

\footnotetext{
${ }^{29}$ European Union $(1992,2002)$.

${ }^{30}$ German Federal Ministry of Justice (2011).

${ }^{31}$ German Federal Ministry of Justice (2008, §4).

32 Zimmermann (1996).

${ }^{33}$ Milbrodt and Helbig (1999).

${ }^{34}$ Fiegenbaum and Thomas (1990).
} 


\section{Company rating $(R A)$}

The next category addresses the perception of the insurer in light of rating agencies. Given the numerous product offerings from different insurers, consumers have to identify the best quality product for their needs. However, they often do not possess the resources or skills to accomplish this task. Many different aspects of product quality are used to form a sound product assessment. Overcoming this challenge, a neutral product assessment by a third party can serve as a guide. In general, De Maeyer and Estelami ${ }^{35}$ point out that third-party product ratings play a vital role in consumer purchase decisions. Hence, we postulate:

H3: Companies with a higher rating are able to achieve a higher new business volume.

\section{Solvency level $(\mathrm{SO})$}

As the foremost goal of regulation, ${ }^{36}$ ensuring adequate solvency levels is not only of concern to the regulator and existing policyholders, but also to new customers. Consumers may pay less or purchase fewer insurance products from an insurer with a higher potential risk of insolvency. ${ }^{37}$ This is particularly important in life insurance products with savings components (for example, pension schemes) even though policyholders are protected against insurer insolvencies through the German industry's guaranty fund Protektor AG (see $w w w . p r o t e k t o r-a g . d e)$. We will include an indicator for the financial strength or solvency ratio of the insurance company in our modelling and hypothesise that:

H4: Higher solvency levels indicate more sales success.

\section{Company size (SI)}

Existing literature analyses the impact of size on different aspects of the insurance industry in several studies. Among others, Hardwick and Adams ${ }^{38}$ examine the impact of size on organic growth rates of life insurance companies in the United Kingdom from 1987 to 1996. The impact of size on firms' competitive behaviour is analysed in Chen and Hambrick. ${ }^{39}$ Ability and willingness to tackle other competitors as well as the response speed to competitors' actions often depends on the size of the firm. We will also examine the impact of size on the ability of insurers to write new business in life insurance. Usually, larger companies have more resources than smaller ones. This can translate through, for example, more sophisticated product development departments, more widespread sales organisations or simply access to larger financial resources. Therefore, we state our fifth hypothesis:

H5: Larger insurers are able to generate higher new business volumes.

\footnotetext{
35 De Maeyer and Estelami (2011).

${ }^{36}$ See, for example, Klein (1995) and Adams and Tower (1994).

37 See Wakker et al. (1997), Brockett et al. (2005) or Zimmer et al. (2009).

${ }^{38}$ Hardwick and Adams (2002).

${ }^{39}$ Chen and Hambrick (1995).
} 


\section{Legal status $(L S)$}

The legal status of the company is also taken into account. We distinguish between mutuals and non-mutuals. This variable has been included in a variety of prior research. Liebenberg and Sommer ${ }^{40}$ include the legal status of the insurer in their analysis of corporate diversification in the P\&C industry. Berry-Stölzle et $a l^{41}$ find that mutual insurers present less unrelated diversification than publicly owned companies. Furthermore, several studies focus on the comparison of efficiency between mutuals and non-mutuals and find empirical evidence of significant differences. ${ }^{42}$ However, when it comes to the analysis of sales, one has to bear in mind that consumers often do not know about the legal status of the company. In addition, in our opinion, it cannot be observed that one of the two company groups has stood out with innovative products or distribution strategies in the past. Thus, we suppose that:

H6: The legal status of the insurer (public or mutual) has no impact on new business growth in life insurance.

\section{Customer satisfaction (SA)}

In addition to accounting, solvency and legal company characteristics, we also include several consumer-related firm evaluations. First, we discuss customer satisfaction. Anderson et al. $^{43}$ show a positive relationship between customer satisfaction and economic performance. Luo et al. ${ }^{44}$ prove significant impact of customer satisfaction on the firm value in light of analyst recommendations. A related phenomenon is highlighted by Mooradian and Olver, ${ }^{45}$ who point out that satisfied customers can attract new ones through word of mouth and thus drive the sales success of a company. Thus, we formulate an additional hypothesis to be analysed in the German life insurance market as follows:

H7: Companies with higher customer satisfaction ratings are able to achieve higher sales rates.

\section{Brand awareness (BA)}

Second, we consider the impact of brand awareness or company recognition on sales success in life insurance. It can be assumed that, when making a buying decision, especially in insurance, consumers take in a first place the products of a company into consideration of which they have already heard. For example, Vogel et al. ${ }^{46}$ point out that brand awareness and perception have an important influence on future sales of the company. We introduce the following additional hypothesis:

H8: Firms with better-known brands among consumers are able to achieve a higher new business volume.

\footnotetext{
${ }^{40}$ Liebenberg and Sommer (2008).

${ }^{41}$ Berry-Stölzle et al. (2012).

42 See, for example, Spiller (1972) and Cummins (1999).

43 Anderson et al. (1994).

${ }^{44}$ Luo et al. (2010).

45 Mooradian and Olver (1997).

${ }^{46}$ Vogel et al. (2008).
} 
Product rating (OT)

Furthermore, we include the assessment of firms' products into our considerations. In Germany, the consumer magazine Oekotest gives grades to single insurance products. This assessment can be interpreted as a product-specific rating. ${ }^{47}$ The importance of ratings or independent third-party opinions on the consumer buying decision has already been pointed out in the context of the above hypotheses (H3). Therefore, we introduce our ninth hypothesis on a product-specific level:

H9: Higher product ratings foster new business volumes.

\section{Price $(P R)$}

Finally, we will consider the average price $P R$ of a policy, which can typically be evaluated for term life insurance. We define it as total premiums for new contracts divided by the number of new contracts. ${ }^{48}$ Because term life insurance is a very homogeneous product, we hypothesise that:

H10: The lower the average price of term life insurance is, the higher the sales success.

\section{Model framework and data set}

Following the introduction of control variables (see Table 2 for an overview) and the development of related hypotheses (H1)-(H10), we develop a multiple linear regression model in order to determine the significant drivers in the sales success of life insurance policies. With new business $N B$ being the dependent or response variable, we test different drivers, both accounting-focused (for example, size, costs, etc.) and customer-related ones (for example, customer satisfaction, brand awareness). In doing so, the approach that we follow is closest to the work of Eling and Kiesenbauer. ${ }^{8}$ In the first part, we formally introduce the regression models which will help us to test our hypotheses of business generation drivers. Some of the observed potential drivers have been applied in prior research by many authors (see the references in the previous section), other variables have-to the best of our knowledge - not yet been tested. In the second part, we present our data gathering, discuss the obtained panel data and provide basic statistical information on the data.

\section{Design of regression models}

In the following we formulate several linear regression models, each incorporating a selection of the introduced variables. First, we will consider a model focusing solely

\footnotetext{
47 The German insurance market is characterised by a multitude of product ratings with very different methodologies and resulting ratings (see Assekurata, 2006a, for an overview and critical discussion). Other ratings include, for example, the ones from the consumer magazine Finanztest (Stiftung Warentest), Capital and Focus Money. However, these ratings are not published on a regular basis and not for all insurance products.

${ }^{48}$ Using this definition we do not take into account the structure of the portfolio, namely the characteristics of the insureds and of the policies (for example, contract length). In practice, even if portfolios may be stable over years, they may differ for individual insurers.
} 
on accounting parameters. The panel data regression model is described by Eq. (1) which reads

$$
N B=\alpha+\beta_{1} R E+\beta_{2} A C+\beta_{3} R A+\beta_{4} S O+\beta_{5} S I+\beta_{6} L S+\varepsilon .
$$

This model includes the six control variables: total return $R E$, acquisition costs $A C$, company rating $R A$, solvency level $S O$, size $S I$ and legal status $L S$ as introduced in the previous section. We will apply this panel data regression to the overall life insurance business (including all life products). Thus $N B$ stands for the overall share of new life business APE in terms of gross written premiums. In Eq. (1), $\alpha$ is the constant or intercept of the equation and $\varepsilon$ represents the standard error or disturbance term. ${ }^{49}$ In order to test the new business drivers and the robustness of our findings, we will apply Eq. (1) to different time periods (subsets) of the panel data. In a reference case (regression R1), we apply the model to the complete panel data which will incorporate the entire 14 years of data from 1998 to 2011. Next we will divide the time period and thus the panel data into three subsamples: (i) first, we test the time period from 1998 until the end of the financial crisis at the beginning of the $21^{\text {st }}$ century, when stock markets regained strength again, that is, 1998-2003, (ii) second, the period of economic recovery until the last financial crisis is analysed, that is, 2004-2008, (iii) third, we test for the drivers in the period after the last financial crisis by taking a look at the period from 2009 to 2011 . Hereinafter, we refer to these three regression analyses as (R2) to (R4).

Further, we extend the reference model by adding control variables related to customer satisfaction $S A$ and brand awareness $B A$. This will allow us to test hypotheses $(\mathrm{H} 7)$ and $(\mathrm{H} 8)$. Because data are not always available for some variables, we will include them in two separate extensions of our regression model. Thus, we introduce the following relation:

$$
N B=\alpha+\beta_{1} R E+\beta_{2} A C+\beta_{3} R A+\beta_{4} S O+\beta_{5} S I+\beta_{6} L S+\beta_{7} S A+\varepsilon,
$$

incorporating the additional control variable $S A$ in the model described in Eq. (1). We will apply this model to the time period from 1998 to 2011 and refer to it as (R5). In addition, we define the model (R6), including the variable brand awareness $B A$ as follows:

$$
N B=\alpha+\beta_{1} R E+\beta_{2} A C+\beta_{3} R A+\beta_{4} S O+\beta_{5} S I+\beta_{6} L S+\beta_{8} B A+\varepsilon .
$$

As mentioned earlier, in addition to testing sales success at the overall business level of life insurance, we also specify the drivers at the level of individual products. We will do so for pension products (including German Riester policies) and term life insurance. In the following we introduce the variables $N B_{P E}$ and $N B_{T L}$ which stand for the new business in pension and term life insurance, respectively. At the product level, product rating data will be available given by $O T_{P E}$ and $O T_{T L}$.

When it comes to pension products, we include the product rating $O T_{P E}$ in our reference model and use product-specific total return data $R E_{P E}$, which translates in our regression model (R7) given by

$$
N B_{P E}=\alpha+\beta_{1} R E_{P E}+\beta_{2} A C+\beta_{3} R A+\beta_{4} S O+\beta_{5} S I+\beta_{6} L S+\beta_{9} O T_{P E}+\varepsilon .
$$

${ }^{49}$ In the panel data regression model each variable and the disturbance term is dependent on the respective life insurance company $i$ (firm effect) and the considered year $t$ (time effect). For ease of notation, we omit the indices $i, t$. 
Table 1 Overview of the defined linear regressions models

\begin{tabular}{lll}
\hline Regression & Level & Model \\
\hline (R1) & Overall life & Reference case for the time period from 1998 to 2011 (see Eq. (1)) \\
(R2) & Overall life & Reference case (R1) but for the time period from 1998 to 2003 \\
(R3) & Overall life & Reference case (R1) but for the time period from 2004 to 2008 \\
(R4) & Overall life & Reference case (R1) but for the time period from 2009 to 2011 \\
(R5) & Overall life & Based on (R1) including the variable customer satisfaction (SA) Eq. (2) \\
(R6) & Overall life & Based on (R1) including the variable brand awareness (BA) Eq. (3) \\
(R7) & Product & Regression for pension insurance Eq. (4) \\
(R8) & Product & Regression for term life insurance Eq. (5) \\
\hline
\end{tabular}

As with pension products, we leave the variables in the reference model unchanged for term life insurance. In contrast to the regression models above, here we exclude the parameter of total return $R E$ from the equation. Because policyholders do not receive an investment return in the traditional term life insurance, this parameter is not of relevance. Instead, we include the term life-specific product rating $O T_{T L}$ and the average product price $P R_{T L}$. The regression equation for our model (R8) then reads:

$$
N B_{T L}=\alpha+\beta_{2} A C+\beta_{3} R A+\beta_{4} S O+\beta_{5} S I+\beta_{6} L S+\beta_{9} O T_{T L}+\beta_{10} P R_{T L}+\varepsilon
$$

An overview of the different regression models is given in Table 1.

\section{Data set definition and statistics}

\section{Data sources}

Following, we detail the data sources for the regression models. On the overall life business level as well as on the two product levels our aim is to cover the period from 1998 to 2011 in our analyses.

All accounting-related data, such as new business figures $N B$, acquisition costs and company size are derived from the individual companies' annual reports. When it comes to the size of the firm SI, we consider the amount of gross written premiums as well as the amount of technical reserves and equity of the insurance company. We define the solvency level $S O$ as the ratio of the book value of equity to total insurance provisions. ${ }^{50}$ Acquisition costs $A C$ are measured as the cost ratio defined as total yearly acquisition costs divided by gross written premiums. Furthermore, we include for each company information about their legal status $L S$, with mutuals coded as 0 vs non-mutual companies coded as 1 . The latter figures have been derived from press research and searches on the companies' websites.

The data on the current total return $R E$ for life policies in the German market were derived from Assekurata ${ }^{51}$ for the years 2004-2011, and Map-Report ${ }^{52}$ for the earlier

\footnotetext{
${ }^{50}$ Note that total provisions include provisions for unit-linked contracts. Since solvency requirements are lower for unit-linked contracts, companies with an above average share of unit-linked contracts are systematically disadvantaged (book value of equity related to unit-linked policies not separately available). In the German market, 14 per cent of life insurance premiums are paid into unit-linked contracts (GDV, 2012, Table 32).

51 Assekurata (2005, 2006b, 2007, 2008, 2009, 2010, 2011).

52 Map-Report (2005).
} 
years 1998-2003. Assekurata analyses on a yearly basis the total returns that policyholders receive for their life insurance policy. In doing so, they distinguish by product type and tariff generation (indicated by the tariff's guarantee rate). The latter is a specialty of the German market and several other European life markets (such as Switzerland, Austria and France). For the current total return $R E$ we consider figures for the most recent tariff generation in the respective year. For example, in 2011, all figures correspond to contracts with a guarantee rate of 2.25 per cent. When it comes to product type, the values shown represent the average of four different product categories: classic whole life insurance, classic annuity insurance and the two German pension schemes "Riester-Rente" and "Ruerup-Rente". Typically, insurers grant the same total return to all these policies. The return figures do not incorporate potential future returns from the policyholder's participation in hidden reserves on the insurer's books, as this participation is not guaranteed and can also be omitted. Therefore, we apply the figures of the total return for the policyholder excluding maturity bonus. The latter is only paid to the policyholder if the policy is kept until maturity. Given a life market lapse rate of 4.3 per cent in Germany in the 2011 Map-Report, ${ }^{53}$ it is clear that many customers will not receive this additional income. Therefore, we exclude it from our analysis. Map-Report does not differentiate between the same product categories as Assekurata does. As a result, a combined average value of the different product types is used in the regression for each year. ${ }^{54}$ It is worth taking a closer look at the historic development of these total return $R E$ figures as well as the corresponding descriptive statistics (see Table 5). One can observe that the remuneration for life insurance policies has declined steadily over the last few years. Although a policyholder received on average a total return of 7.2 per cent in 1998, he only gets 4.1 per cent in 2011. This trend can be observed across the entire market. There are variations in return figures among individual companies (different minimum and maximum values), but the standard deviation is relatively small. This indicates that large parts of the industry provide quite homogeneous investment returns for their policyholders.

Figures for insurance company ratings (variable $R A$ ) are derived from two different sources. First, and in order to be able to compare our results to Eling and Kiesenbauer, ${ }^{8}$ we make use of the so-called "Finsinger rating". 55 This rating is available for the years 1999-2011 and reported by Wirtschaftswoche. ${ }^{56}$ Second, we include the yearly life insurer ratings of Morgen \& Morgen (called the "M\&M rating"), a German rating company that also provides detailed analyses for financial service products. Their ratings are publicly available at www.morgenundmorgen.com for the years 1998-2011. The M\&M rating combines different key figures for insurance companies, among others, cost ratios, financial strength,

\footnotetext{
53 Map-Report (2012).

54 As mentioned before, our approach is close to that of Eling and Kiesenbauer (2012). The authors state that they use the arithmetic average of all tariff generations (Eling and Kiesenbauer, 2012, p. 174). Our analysis, however, is based on the figures for the latest tariff generation, since this represents the only policy category that new customers can invest in. In addition, we do not model the rate relative to the market average, since it can be assumed that a potential policyholder is interested in the absolute return he or she might receive from the policy. Because this figure is fixed in the first quarter of year, we can directly link the values to the new business of the same accounting year and do not have to adjust for potential time discrepancies.

55 This rating by Finsinger, a scientist in the Department of Finance at the University of Vienna, is published once a year in the magazine Wirtschaftswoche, a national German weekly economic journal.

${ }^{56}$ Wirtschaftswoche (1999, 2000, 2001, 2002, 2003, 2004, 2005, 2006, 2008, 2009, 2010, 2011, 2007a).
} 
investment performance and lapse volumes. Both the Finsinger rating and the M\&M rating provide a scale of 1 to 5 ("stars"), with 5 being the best.

The company YouGov, formerly known as Psychonomics, regularly conducts a representative survey across Germany in which also the customer satisfaction in different dimensions is analysed. These dimensions include, for example, overall satisfaction with a company, as well as satisfaction with premium levels, service and the salesforce. We use the empirically observed values for overall satisfaction with the insurer as input for our customer satisfaction variable SA. Data points are available for the years 2003, 2008 and $2010 .^{57}$ Wherever years are not covered by available data in our analysis, we interpolate linearly the figures for the respective year. No data are available before 2003 .

Data for brand awareness are derived from reports by the German magazine Stern. ${ }^{58}$ In 2003, 2005 and 2007, Stern conducted representative statistical surveys on the brand recognition of different companies in Germany, including insurers. In these surveys, interviewees were asked to rate the company with respect to perceived publicity, sympathy and their willingness to buy from the insurer (on a scale from 1 to 5). We linearly interpolate the missing years 2004 and 2006 so as to get a continuous data sample from 2003 to 2007 . No additional studies were conducted before 2003 or after 2007.

In addition, when it comes to the product-specific level, we include the rating $O T$ for individual life insurance products. Therefore, we use the assessments of the magazine Oekotest. An evaluation for pension insurance ("Riester-Rente") products is available for the years 2007, 2008, 2009 and $2011^{59}$ and for term life insurance for the years 2007, 2008 and $2010 .^{60}$ The assessment provided is based on the German school grading system, ranging from 1 (very good) to 6 (fail). If several products of one insurer are tested, we use the best rating. In the individual tests, data are aggregated for different types of customers, for example, male, 30 years old, non-smoking, or female, 40 years old, smoking. We use the average values for all provided combinations. Missing annual values are again linearly interpolated.

An overview of the variables introduced in the previous section "Development of research hypotheses" and the above described sources for the data is provided in Table 2.

\section{Market coverage}

Furthermore, Table 3 shows figures representing the amount of market coverage. The covered share of premiums in terms of market premiums as well as the number of available company data points are given for each year. The figures show that, on the level of overall business, data availability is very good, reaching levels of 100 per cent for accounting data. Most of the variables-see in particular also total return $R E$ and the ratings $R A$ - are available for companies whose premium volume represents more than 90 per cent of the market's gross written premiums. For the early years of our analysis, the return figures and the rating variables are slightly less well covered. However, the available data points always cover more than 70 per cent of the market's premiums. The variables customer satisfaction

\footnotetext{
57 See YouGov (2003), YouGov (2008) and YouGov (2010).

58 Stern $(2003,2005,2008)$.

59 See Oekotest (2007a, 2008b, 2009, 2011).

${ }^{60}$ See Oekotest (2007b, 2008a, 2010).
} 
Table 2 Overview of introduced variables and related data sources

\begin{tabular}{|c|c|c|c|}
\hline Description & Variable & Description & Source \\
\hline New business & $N B$ & $\begin{array}{l}\text { New business annual premium equivalent to total } \\
\text { gross written premiums }\end{array}$ & Companies' annual reports \\
\hline Total return & $R E$ & $\begin{array}{l}\text { Return rate to policyholders including maximum } \\
\text { guarantee rate and surplus participation component }\end{array}$ & $\begin{array}{l}\text { Assekurata } \\
\text { Map-Report }^{52} \text { and }\end{array}$ \\
\hline Acquisition costs & $A C$ & $\begin{array}{l}\text { Ratio of total acquisition costs to gross written } \\
\text { premiums (cost ratio) }\end{array}$ & Companies' annual reports \\
\hline Company rating & $R A$ & $\begin{array}{l}\text { Average of Finsinger rating and Morgen \& } \\
\text { Morgen rating }\end{array}$ & $\begin{array}{l}\text { Wirtschaftswoche }{ }^{56} \text { and } \\
\text { www.morgenundmorgen. } \\
\text { com) }\end{array}$ \\
\hline Solvency level & SO & $\begin{array}{l}\text { Ratio of the book value of equity to the total } \\
\text { insurance provisions }\end{array}$ & Companies' annual reports \\
\hline Company size & $S I$ & Average of premiums, equity and reserves & Companies' annual reports \\
\hline Legal status & $L S$ & Mutual (0) or non-mutual status (1) of the firm & $\begin{array}{l}\text { Companies' annual reports } \\
\text { and websites }\end{array}$ \\
\hline Customer satisfaction & $S A$ & Stern rating & Stern $^{58}$ \\
\hline Brand awareness & $B A$ & YouGov rating & YouGov $^{57}$ \\
\hline Product rating & $O T$ & $\begin{array}{l}\text { Oekotest rating for pension insurance (PE) and } \\
\text { term life insurance (TL) }\end{array}$ & $\begin{array}{l}\text { PE: Oekotest } \\
\text { Oekotest }^{59}, \mathrm{TL}\end{array}$ \\
\hline Price (term life) & $P R$ & $\begin{array}{l}\text { Ratio of total premiums for new contracts to } \\
\text { number of new contracts }\end{array}$ & Companies' annual reports \\
\hline
\end{tabular}

$S A$ and brand awareness $B A$ are not available for all years. As previously noted, they are also interpolated for several observation periods (see values marked with $*$ in Table 3 ).

On the product-specific level, data availability is less comprehensive. Although new business figures for both products, $N B_{P E}$ and $N B_{T L}$, can still be fully derived, the product assessment by the magazine Oekotest was only introduced in 2007 and thus leads to a reduction of the panel data for several years. Furthermore, it must be noted that third-party sources (Oekotest, as well as Stern and YouGov) do not aim to cover the entire industry, which is reflected in the lower rates of market coverage. ${ }^{61}$

\section{Descriptive statistics}

Table 4 provides descriptive statistics for the independent variable $N B$, that is, the share of new business, in our regression models. The proportion of new business of the total gross written premiums in life insurance has shrunk steadily over the last few years. Even small increases in new business generation such as in 2004, when legal changes were to take place in the next year and purchases by customers were brought forward, could not stop this trend.

Table 5 presents the summary statistics of a selection of the panel data control variables. We report basic statistics on the gross written premiums, equity and reserves, displaying the mean, minimum, maximum, several quantile values and the standard deviation of their

${ }^{61}$ Overall, we use unprocessed data, that is, if mergers or name changes of insurers occur, we ignore them historically and include the new data point in the respective year in our analysis and leave the historic names or companies in the future blank. 
Table 3 Data availability and market coverage of the variables used in the panel data

\begin{tabular}{|c|c|c|c|c|c|c|c|c|c|c|c|c|c|c|}
\hline Year & $' 98$ & $' 99$ & 'OO & '01 & '02 & '03 & '04 & '05 & '06 & '07 & '08 & '09 & 10 & 11 \\
\hline \multicolumn{15}{|c|}{ Overall life insurance business variables } \\
\hline \multirow{2}{*}{$\begin{array}{l}N B, A C, S O \\
\text { SI } L S\end{array}$} & $98 \%$ & $98 \%$ & $100 \%$ & $100 \%$ & $100 \%$ & $99 \%$ & $100 \%$ & $100 \%$ & $100 \%$ & $100 \%$ & $100 \%$ & $100 \%$ & $100 \%$ & $100 \%$ \\
\hline & 114 & 112 & 116 & 115 & 106 & 103 & 101 & 100 & 97 & 98 & 98 & 98 & 97 & 92 \\
\hline \multirow[t]{2}{*}{$R E$} & $72 \%$ & $71 \%$ & $73 \%$ & $73 \%$ & $76 \%$ & $77 \%$ & $94 \%$ & $90 \%$ & $92 \%$ & $91 \%$ & $92 \%$ & $91 \%$ & $91 \%$ & $95 \%$ \\
\hline & 69 & 68 & 69 & 69 & 69 & 67 & 79 & 81 & 81 & 75 & 79 & 79 & 76 & 72 \\
\hline \multirow[t]{2}{*}{$R A$ (Finsinger) } & - & $86 \%$ & $94 \%$ & $90 \%$ & $91 \%$ & $92 \%$ & $94 \%$ & $92 \%$ & $94 \%$ & $94 \%$ & $94 \%$ & $90 \%$ & $90 \%$ & $93 \%$ \\
\hline & - & 78 & 81 & 77 & 79 & 75 & 72 & 72 & 74 & 75 & 77 & 71 & 71 & 69 \\
\hline & 65 & 66 & 65 & 68 & 68 & 75 & 75 & 77 & 77 & 77 & 75 & 75 & 70 & 69 \\
\hline \multirow[t]{2}{*}{$S A$} & - & - & - & - & - & $63 \%$ & $62 \% *$ & $63 \% *$ & $65 \% *$ & $66 \% *$ & $70 \%$ & $69 \% *$ & $74 \%$ & - \\
\hline & - & - & - & - & - & 27 & $26^{*}$ & $26 *$ & $27 *$ & $27 *$ & 32 & $30 *$ & 35 & - \\
\hline \multirow[t]{2}{*}{$B A$} & - & - & - & - & - & $72 \%$ & $76 \% *$ & $77 \%$ & $72 \% *$ & $75 \%$ & - & - & - & - \\
\hline & - & - & - & - & - & 38 & $39 *$ & 42 & $31 *$ & 33 & - & - & - & - \\
\hline \multicolumn{15}{|c|}{ Product-specific variables } \\
\hline \multirow[t]{2}{*}{$N B_{P E}$} & $91 \%$ & $96 \%$ & $98 \%$ & $98 \%$ & $98 \%$ & $98 \%$ & $99 \%$ & $99 \%$ & $98 \%$ & $99 \%$ & $98 \%$ & $98 \%$ & $98 \%$ & $98 \%$ \\
\hline & 109 & 109 & 110 & 109 & 100 & 99 & 97 & 96 & 94 & 93 & 92 & 91 & 90 & 88 \\
\hline & - & - & - & - & - & - & - & - & - & 26 & 26 & 21 & $15^{*}$ & 18 \\
\hline \multirow[t]{2}{*}{$N B_{T L}, \quad P R$} & $96 \%$ & $96 \%$ & $98 \%$ & $98 \%$ & $98 \%$ & $98 \%$ & $99 \%$ & $99 \%$ & $98 \%$ & $98 \%$ & $99 \%$ & $98 \%$ & $98 \%$ & $98 \%$ \\
\hline & 106 & 106 & 106 & 107 & 99 & 98 & 96 & 97 & 93 & 92 & 92 & 91 & 89 & 87 \\
\hline \multirow[t]{2}{*}{$O T_{T L}$} & - & - & - & - & - & - & - & - & - & $60 \%$ & $64 \%$ & $27 \% *$ & $43 \%$ & - \\
\hline & - & - & - & - & - & - & - & - & - & 36 & 46 & $22 *$ & 33 & - \\
\hline
\end{tabular}

Note: Data coverage is expressed as a share of market premiums in the respective year (per cent figures). The numbers below represent the number of companies. *denotes missing underlying data; however, data have been interpolated. Company size $S I$ is based on gross written premiums, equity and reserves. Company rating $R A$ is based on Morgen \& Morgen (M\&M) and Finsinger ratings. 
Table 4 Descriptive statistics for the share of new business $N B$ (overall) and in the product lines pension insurance $N B_{P E}$ and term life insurance $N B_{T L}$

\begin{tabular}{|c|c|c|c|c|c|c|c|c|c|c|c|c|c|c|}
\hline Year & '98 & $' 99$ & $' 00$ & '01 & '02 & '03 & '04 & '05 & '06 & '07 & '08 & '09 & 10 & $' 11$ \\
\hline \multicolumn{15}{|c|}{ New business share NB (overall life business) } \\
\hline Mean & 15.0 & 21.4 & 12.9 & 17.0 & 13.6 & 14.9 & 19.9 & 12.2 & 11.9 & 11.5 & 11.3 & 9.9 & 10.1 & 10.4 \\
\hline Min. & 0.0 & 3.2 & 0.0 & 0.0 & 0.0 & 0.1 & 0.0 & 1.0 & 0.4 & 1.1 & 2.1 & 2.2 & 0.0 & 0.0 \\
\hline $25 \%$ Ptl. & 10.2 & 14.5 & 7.9 & 8.7 & 9.9 & 11.2 & 12.7 & 7.0 & 8.4 & 7.9 & 8.3 & 7.4 & 8.0 & 8.1 \\
\hline Median & 12.1 & 18.0 & 10.0 & 11.2 & 11.5 & 13.6 & 17.7 & 9.7 & 11.0 & 9.8 & 10.4 & 9.2 & 9.5 & 9.8 \\
\hline $75 \%$ Ptl. & 16.6 & 23.9 & 14.5 & 14.6 & 14.0 & 16.5 & 23.8 & 12.6 & 13.4 & 11.7 & 12.4 & 11.7 & 11.7 & 12.3 \\
\hline Max. & 80.0 & 84.2 & 68.8 & 407.5 & 96.5 & 54.3 & 67.8 & 174.4 & 54.0 & 121.6 & 59.4 & 29.3 & 30.4 & 30.5 \\
\hline St. Dev. & 10.6 & 13.7 & 9.8 & 37.8 & 10.9 & 7.5 & 10.8 & 17.2 & 6.5 & 12.3 & 6.9 & 4.6 & 4.5 & 4.7 \\
\hline \multicolumn{15}{|c|}{ New business share for pension products $N B_{P E}$} \\
\hline Mean & 29.6 & 37.1 & 19.0 & 20.9 & 23.5 & 22.5 & 30.4 & 16.9 & 17.1 & 15.2 & 15.6 & 13.0 & 12.7 & 13.8 \\
\hline Min. & 0.6 & 0.8 & 0.8 & 0.1 & 1.0 & 0.1 & 2.7 & 0.4 & 1.4 & 0.7 & 0.8 & 1.6 & 1.4 & 1.4 \\
\hline $25 \%$ Ptl. & 18.2 & 24.9 & 11.5 & 13.3 & 14.1 & 15.2 & 20.4 & 8.6 & 10.2 & 8.7 & 9.5 & 8.2 & 8.1 & 9.4 \\
\hline Median & 23.2 & 35.2 & 15.3 & 17.6 & 19.4 & 19.2 & 27.8 & 11.9 & 13.8 & 13.3 & 15.0 & 11.8 & 12.3 & 14.0 \\
\hline $75 \%$ Ptl. & 33.2 & 44.6 & 21.2 & 25.5 & 24.9 & 26.0 & 36.1 & 18.2 & 18.8 & 16.7 & 18.4 & 16.1 & 15.9 & 16.7 \\
\hline Max. & 100.0 & 100.2 & 100.0 & 107.0 & 105.0 & 88.1 & 100.3 & 100.0 & 87.4 & 100.0 & 78.3 & 44.9 & 35.9 & 38.3 \\
\hline St. Dev. & 20.9 & 19.7 & 15.2 & 16.4 & 18.3 & 13.8 & 15.2 & 16.8 & 13.0 & 12.6 & 10.5 & 7.2 & 6.5 & 7.3 \\
\hline \multicolumn{15}{|c|}{ New business share for term life products $N B_{T L}$} \\
\hline Mean & 22.0 & 20.5 & 19.1 & 21.7 & 19.8 & 18.6 & 18.0 & 16.3 & 16.0 & 15.4 & 13.4 & 12.3 & 12.0 & 10.9 \\
\hline Min. & 2.1 & 2.2 & 0.8 & 0.1 & 1.4 & 0.6 & 0.1 & 0.0 & 0.8 & 0.1 & 1.0 & 0.0 & 0.1 & 0.1 \\
\hline $25 \%$ Ptl. & 13.9 & 12.1 & 10.7 & 12.8 & 12.4 & 11.9 & 10.8 & 8.9 & 10.3 & 9.5 & 8.2 & 7.7 & 7.3 & 6.9 \\
\hline Median & 18.2 & 17.1 & 14.4 & 16.7 & 15.2 & 16.7 & 15.1 & 13.9 & 14.4 & 12.5 & 11.5 & 11.9 & 10.8 & 10.9 \\
\hline $75 \%$ Ptl. & 23.5 & 22.8 & 21.3 & 25.5 & 22.4 & 22.9 & 20.3 & 18.6 & 17.8 & 17.1 & 15.8 & 15.0 & 14.1 & 13.4 \\
\hline Max. & 100.5 & 100.7 & 101.3 & 100.0 & 104.9 & 69.9 & 100.0 & 79.8 & 100.5 & 80.3 & 49.3 & 42.9 & 45.9 & 31.3 \\
\hline St. Dev. & 17.0 & 16.1 & 17.5 & 17.1 & 16.3 & 11.6 & 13.7 & 12.6 & 12.7 & 12.7 & 9.1 & 7.9 & 8.1 & 6.4 \\
\hline
\end{tabular}

Note: Values for new business are sales values for the respective companies in the observed year. New business share is calculated as a percentage of new business APE in terms of total gross written premiums. "Mean" denotes the arithmetic average of all companies, "Min."/"Max." the minimum/maximum value found in the sample, "Ptl." stands for percentile and "St. Dev." is an abbreviation for the standard deviation. 
Table 5 Summary statistics for selected panel data control variables

\begin{tabular}{|c|c|c|c|c|c|c|c|c|c|c|c|c|c|c|}
\hline Year & $' 98$ & '99 & $' 00$ & $' 01$ & '02 & '03 & $' 04$ & '05 & '06 & '07 & '08 & '09 & $' 10$ & 11 \\
\hline \multicolumn{15}{|c|}{ Gross written premiums (in $m €$ ) } \\
\hline Mean & 428 & 494 & 515 & 512 & 576 & 618 & 632 & 685 & 718 & 730 & 745 & 803 & 878 & 863 \\
\hline Min. & 0 & 0 & 0 & 0 & 0 & 0 & 0 & 0 & 0 & 0 & 0 & 0 & 0 & 0 \\
\hline $25 \%$ Ptl. & 31 & 33 & 24 & 26 & 37 & 47 & 47 & 57 & 53 & 57 & 57 & 60 & 74 & 78 \\
\hline Median & 144 & 155 & 128 & 126 & 148 & 191 & 189 & 194 & 215 & 204 & 195 & 199 & 207 & 214 \\
\hline $75 \%$ Ptl. & 445 & 517 & 540 & 540 & 635 & 648 & 724 & 802 & 846 & 858 & 852 & 855 & 954 & 986 \\
\hline Max. & 7,304 & 8,252 & 8,426 & 8,310 & 9,648 & 10,332 & 10,560 & 11,787 & 12,518 & 12,754 & 12,927 & 14,357 & 15,398 & 14,829 \\
\hline St. Dev. & 826 & 955 & 989 & 985 & 1,136 & 1,212 & 1,235 & 1,356 & 1,435 & 1,470 & 1,519 & 1,670 & 1,824 & 1,773 \\
\hline \multicolumn{15}{|c|}{ Equity (in $m €$ ) } \\
\hline Mean & 49 & 54 & 59 & 59 & 68 & 80 & 90 & 96 & 105 & 110 & 115 & 126 & 120 & 126 \\
\hline Min. & 2 & 2 & 2 & 0 & 0 & 0 & 0 & 0 & 0 & 0 & 0 & 3 & 3 & 3 \\
\hline $25 \%$ Ptl. & 6 & 6 & 7 & 7 & 7 & 9 & 9 & 11 & 11 & 12 & 13 & 16 & 17 & 19 \\
\hline Median & 19 & 21 & 20 & 21 & 28 & 32 & 35 & 38 & 43 & 45 & 49 & 52 & 46 & 52 \\
\hline $75 \%$ Ptl. & 48 & 52 & 56 & 54 & 84 & 103 & 116 & 131 & 145 & 147 & 157 & 162 & 147 & 154 \\
\hline Max. & 849 & 940 & 1,074 & 1,153 & 1,197 & 1,276 & 1,307 & 1,396 & 1,411 & 1,456 & 1,459 & 1,652 & 1,691 & 1,759 \\
\hline St. Dev. & 96 & 107 & 121 & 123 & 132 & 146 & 165 & 171 & 181 & 186 & 191 & 210 & 211 & 218 \\
\hline \multicolumn{15}{|c|}{ Reserves (in bn $€$ ) } \\
\hline Mean & 3.4 & 3.9 & 4.2 & 4.3 & 4.8 & 5.1 & 5.3 & 5.8 & 6.2 & 6.6 & 6.6 & 7.1 & 7.6 & 8.0 \\
\hline Min. & 0.0 & 0.0 & 0.0 & 0.0 & 0.0 & 0.0 & 0.0 & 0.0 & 0.0 & 0.0 & 0.0 & 0.0 & 0.0 & 0.0 \\
\hline $25 \%$ Ptl. & 0.1 & 0.1 & 0.1 & 0.1 & 0.1 & 0.2 & 0.2 & 0.3 & 0.3 & 0.3 & 0.3 & 0.4 & 0.4 & 0.4 \\
\hline Median & 0.8 & 0.9 & 0.9 & 0.8 & 0.9 & 1.1 & 1.2 & 1.2 & 1.6 & 1.7 & 1.5 & 1.8 & 2.0 & 2.2 \\
\hline $75 \%$ Ptl. & 4.2 & 4.2 & 4.7 & 4.5 & 4.8 & 5.1 & 5.5 & 5.7 & 6.3 & 6.4 & 6.1 & 6.4 & 7.0 & 7.5 \\
\hline Max. & 65.0 & 70.2 & 75.2 & 79.5 & 88.9 & 92.7 & 96.6 & 106.7 & 113.2 & 121.3 & 124.1 & 131.2 & 137.9 & 143.0 \\
\hline St. Dev. & 7.2 & 8.0 & 8.7 & 9.1 & 10.2 & 10.7 & 11.1 & 12.2 & 13.0 & 14.0 & 14.4 & 15.2 & 16.2 & 17.0 \\
\hline \multicolumn{15}{|c|}{ Total return RE (in per cent) } \\
\hline Mean & 7.17 & 7.20 & 7.13 & 7.06 & 6.14 & 4.85 & 4.38 & 4.33 & 4.24 & 4.27 & 4.38 & 4.27 & 4.19 & 4.07 \\
\hline Min. & 4.50 & 6.00 & 5.50 & 6.00 & 4.50 & 3.25 & 3.00 & 3.00 & 3.37 & 3.47 & 3.50 & 3.50 & 3.25 & 3.40 \\
\hline
\end{tabular}




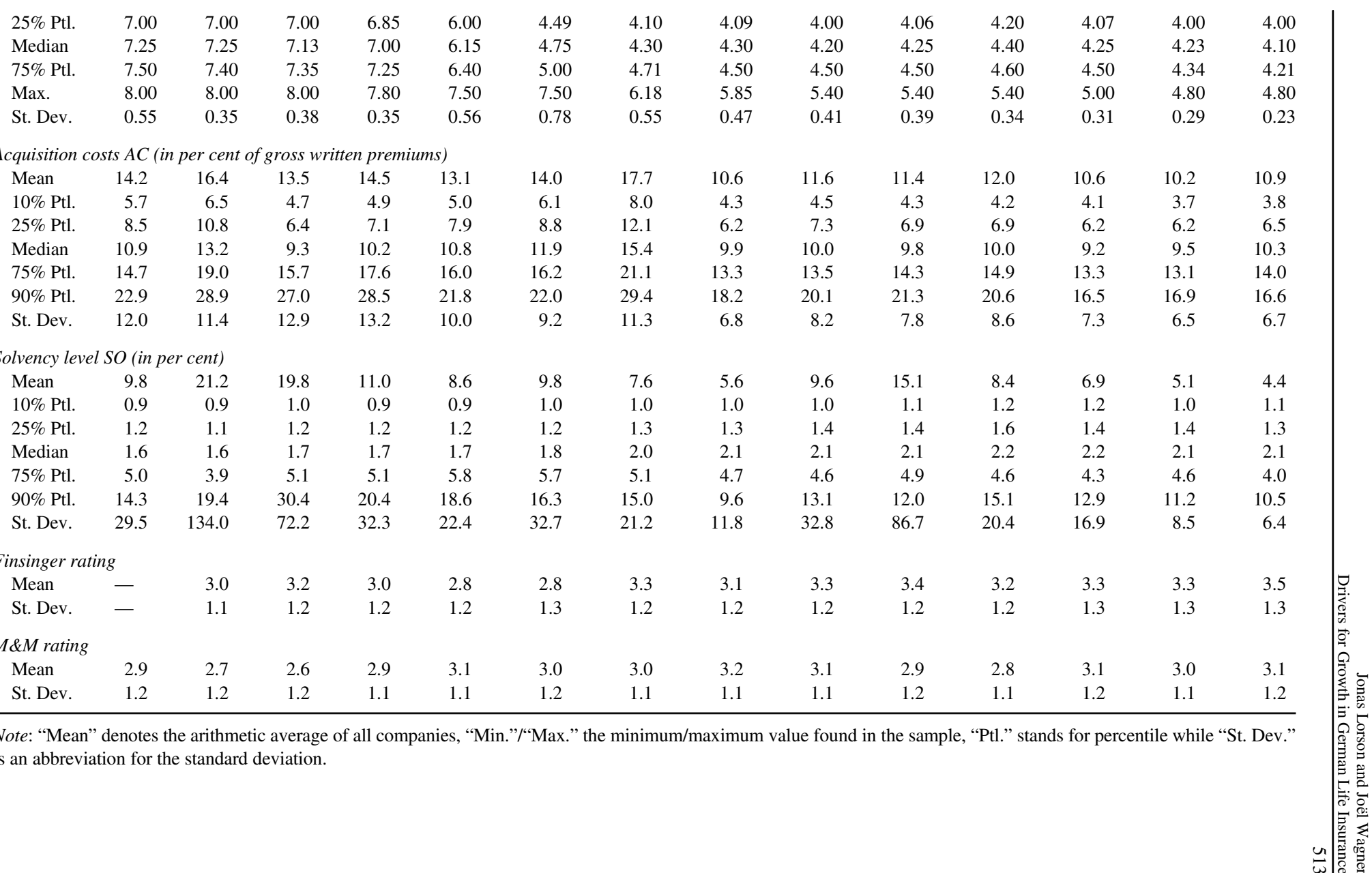


Table 6 Empirical results of the reference multiple linear regression model (R1) on sales success in German life insurance

\begin{tabular}{lrcccr}
\hline Variables & Est. $\left(\beta_{i}\right)$ & St. error & $p$-value & Sig. & Stand. $\beta_{i}$ \\
\hline$\alpha$ & -0.0336 & 0.0079 & 0.0000 & $* * *$ & \\
$R E$ & 0.3405 & 0.1039 & 0.0011 & $* *$ & 0.0801 \\
$A C$ & 0.6727 & 0.0263 & 0.0000 & $* * *$ & 0.6621 \\
$R A$ & 0.0167 & 0.0013 & 0.0000 & $* * *$ & 0.3293 \\
$S O$ & 0.2890 & 0.0525 & 0.0000 & $* * *$ & 0.1402 \\
$S I$ & -0.0000 & 0.0000 & 0.0181 & $* *$ & -0.0600 \\
$L S$ & 0.0034 & 0.0031 & 0.2684 & & 0.0277
\end{tabular}

Adjusted $R^{2}$

0.4747

Note: The two-tailed $t$-statistics are provided: *,** and $* * *$ represent the respective significance at the 10,5 and 1 per cent levels. "Stand. $\beta_{i}$ " stands for standardised beta coefficients.

respective distributions in the different years from 1998 to 2011. Further statistics are provided for total policy return $R E$, acquisition costs $A C$ and solvency level $S O$. Finally, the mean and standard deviation of the Finsinger and $M \& M$ ratings are provided. With respect to the premium volume (gross written premiums), the dispersed minimum and maximum values show that the insurer sample covers a broad range of companies in terms of size. The smallest firms account for less than $€ 1 \mathrm{~m}$ annually, while the largest is $€ 14$.8bn (in 2011). When looking at the data, we further notice that the distribution in terms of premium volume of the companies in the panel positively skewed, that is, presents a right tail distribution. Similar effects are slightly present when it comes to the reserves, acquisition costs $A C$ and solvency levels $S O$.

\section{Empirical results and discussion}

The section "Overall growth drivers in life insurance" describes the results on the overall life insurance business level. Overall success drivers for the sale of life insurance policies in Germany are presented, before the section "Product-specific growth drivers" goes a step deeper and analyses the impact at a product-specific level, that is, pension and term life insurance.

\section{Overall growth drivers in life insurance}

Before running our regression model, we test our panel data for multi-collinearity among the variables. We conduct a maximum-likelihood factor analysis to detect latent meta constructs which we should include in our analysis. In this way, the correlation between similar items should be high while variables that are not related should have low correlations. As expected, the factor analysis yields a strong correlation between variables used to characterise firm size: premium volume, equity and reserves. Observed factor loadings higher than 0.95 are not surprising, since all parameters are closely related to the insurer's size. For the regression model, we therefore combine these three items by taking the average for the size parameter SI. The internal consistency has been measured with the help of Cronbach's alpha. It yields 
a value of 0.953 on a scale with a maximum value of 1 . Values higher than 0.7 indicate internal consistency of the variables. Furthermore, given the heavily rightward-skewed distribution of the parameter values (see Table 5), we consider the natural logarithm of the average of premiums, equity and reserves for SI. Another item battery has been detected with the help of the factor analysis. It is also not surprising that the company ratings by both Finsinger and Morgen \& Morgen present high factor loadings above 0.7. This result was to be expected, as both items are ratings for life insurers and have several rating criteria in common. We combine the two ratings by taking their average for the regression model and use this average as the company rating variable $R A$. For this factor, Cronbach's alpha yields 0.814 and thus supports the consistency of the two variables. The factor analysis yields no further groups of items which should be combined into one factor. However, it still reveals a strong factor loading for both total return $R E$ and solvency level $S O$. Since the variables total return $R E$, acquisition costs $A C$, solvency level $S O$ and legal status $L S$ show no strong correlation with any other variable, we include them as single independent variables in the regression model. ${ }^{62}$

\section{Reference model (RI)}

Having checked our initial data sample for multi-collinearity, we now apply the reference regression model (R1) to the full panel data to derive drivers for sales success in German life insurance (recall the overview of regression models in Table 1). In the period from 1998 to 2011, and for the relevant variables in the model (R1), a total of $N=895$ full data points or firm-years are available. The results of the regression model for the reference case and full panel data as well as additional statistics are reported in Table 6. We report the estimated betacoefficients corresponding to the different control variables of (R1) with their corresponding standard error. Further, we present the results of the two-tailed $t$-statistics including $p$-value and significance. Here, $* * *$ and $* * *$ represent the significance at the 10,5 and 1 per cent levels, respectively. Finally, we calculate and report the standardised beta coefficient in order to be able to compare the magnitude of the impact of the different variables. ${ }^{63}$

The linear regression model (R1) is able to explain about 48 per cent (adjusted $R^{2}$ value of 0.4747 , see Table 6 ) of the variance and yields several significant variables. Five control variables, namely total return $R E$, acquisition costs $A C$, company rating $R A$, solvency level $S O$ and company size $S I$, show a significant impact. The variables return $R E$ and size $S I$ are significant at the 5 per cent level. At a 1 per cent level of significance, three further variables were detected: costs $A C$, rating $R A$ and solvency $S O$. Only the control variable legal status $L S$ has no explanatory power in our empirical findings.

${ }^{62}$ Bartlett's test of sphericity for the factor analysis yielded 335.08 on 12 degrees of freedom. This value is higher than the chi-square reference value and thus the feasibility of the factor analysis is confirmed.

${ }^{63}$ In order to further test the robustness of our results, we conducted several analyses. In order to check for the absence of multi-collinearity in the applied data set in model (R1), we test the variance inflation factors (VIF) of the model. All values are below the commonly accepted threshold of 10; the highest VIF in our model yields 1.15. In order to test for autocorrelation of the standard errors we conducted the Durbin-Watson test. The result of 1.3 is close to the commonly accepted range of 1.5 to 2.5 , in which no autocorrelation can be assumed to exist. Finally, we tested for heteroscedasticity. The visual plot of the residuals as well as the Goldfeld-Quandt test yielded no proof of inhomogeneous variance in error terms. We also plotted the results of our regression model and found no indications that the model was inaccurate. Details are available upon request from the authors. 
516

First, it can be observed that higher acquisition costs per premium, that is, higher monetary incentives for the salesforce, strongly drive the generation of new life insurance contracts. Thus, the second hypothesis (H2) is validated (see the section "Development of research hypotheses"). This finding thus underlines the importance of the distribution network and the need for adequate incentives. Second, the higher or the better the rating of the insurance company is, the higher the new business generation was in the past. The same effect is observed when it comes to the solvency of the insurer, and the same relation holds true for the total return that policyholders receive from the company. These findings confirm the initial hypotheses (H1), (H3) and (H4). These results can be interpreted intuitively since higher returns for customers, better company ratings and higher solvency levels are expected to be new business generators. In contrast to our initial hypothesis (H5), the size of the insurer has a small negative impact on sales success; this hypothesis is not validated. The relatively small negative coefficient may indicate that size has not a large influence, and that customers may prefer smaller or more local players. Furthermore this may be explained through lower growth rates in a mature market (see also Eling and Kiesenbauer, ${ }^{8}$ p. 178). Having no significant impact, the legal status of a firm can be omitted in terms of new premium growth. This confirms the last hypothesis (H6) in our reference case and may be due to the fact that policyholders often do not know about the legal status when choosing their insurer. When it comes to the magnitude of the impact from significant drivers, the standardised beta coefficients show that the acquisition costs $A C$ (standardised $\beta_{i}=0.66$ ), that is, the commissions the insurer pays, has the highest influence; it is more than two times higher than the second strongest driver, company rating $R A$ (standardised $\beta_{i}=0.33$ ). The solvency level $S O$ of the company (standardised $\beta_{i}=0.14$ ) as well as the achieved total return $R E$ for the policyholder (standardised $\beta_{i}=0.08$ ) are more or less of equal impact and contribute the least in a positive way towards sales success among the significant variables. As mentioned above, the negative impact of size on the ability to generate new business is relatively small.

Our results confirm and extend the findings of Eling and Kiesenbauer ${ }^{8}$ in several ways. We are able to confirm the positive impact of policyholder participation (or policyholder total return) as well as the negative impact of firm size on the generation of new business for the entire period from 1998 to 2011 (see Eling and Kiesenbauer, ${ }^{8}$ Table 2). Second, we complement that knowledge with information about the impact of further control variables, especially the important impact of acquisition costs $A C$.

\section{Models for different time horizons: Comparing (R1) through (R4)}

Repeating our analysis for shorter time intervals using the regression models (R2), (R3) and (R4), we confirmed the above results. Table 7 summarises the standardised beta coefficients and significance levels for (R1)-(R4) on the overall business level for different time periods.

Within regression model (R2), which addresses the period from 1998 to 2003 until a recovery of stock markets set in after the financial crisis of the early 2000s, all previous significant variables are also significant at the same level-except for total return $R E$, which is no longer significant. In total, the adjusted $R^{2}$ of the regression model is 0.398 . Similarly, model (R3) in the second time period from 2004 to 2008 confirms the previous findings. However, in this case, total return $R E$ is again significant at the 10 per cent level with a positive impact on new business generation. The explanatory power of this model is 0.565 . It seems that during periods of crisis and declining stock markets, the overall return of life 
Table 7 Empirical results for regression models (R1) through (R4) on sales success in German life insurance for different time periods

\begin{tabular}{|c|c|c|c|c|c|c|c|c|}
\hline \multirow{3}{*}{$\begin{array}{l}\text { Regression model } \\
\text { Time period } \\
\text { Variables }\end{array}$} & \multicolumn{2}{|c|}{$(R 1)$} & \multicolumn{2}{|c|}{$(R 2)$} & \multicolumn{2}{|c|}{ (R3) } & \multicolumn{2}{|c|}{ (R4) } \\
\hline & \multicolumn{2}{|c|}{ 1998-2011 } & \multicolumn{2}{|c|}{$1998-2003$} & \multicolumn{2}{|c|}{ 2004-2008 } & \multicolumn{2}{|c|}{ 2009-2011 } \\
\hline & Stand. $\beta_{i}$ & Sign. & Stand. $\beta_{i}$ & Sign. & Stand. $\beta_{i}$ & Sign. & Stand. $\beta_{i}$ & Sign. \\
\hline$R E$ & 0.0801 & $* *$ & -0.0291 & & 0.0887 & * & -0.1214 & $*$ \\
\hline$A C$ & 0.6621 & $* * *$ & 0.6270 & $* * *$ & 0.6818 & $* * *$ & 0.6493 & *** \\
\hline$R A$ & 0.3293 & $* * *$ & 0.4134 & $* * *$ & 0.3161 & $* * *$ & 0.2495 & *** \\
\hline SO & 0.1402 & $* * *$ & 0.1268 & $* * *$ & 0.1563 & $* * *$ & 0.0484 & \\
\hline$S I$ & -0.0600 & $* *$ & -0.0873 & $* *$ & -0.0854 & $* *$ & 0.0606 & \\
\hline$L S$ & 0.0277 & & 0.0698 & & 0.0160 & & -0.0442 & \\
\hline Adjusted $R^{2}$ & 0.4747 & & 0.39 & & 0.5654 & & 0.3848 & \\
\hline
\end{tabular}

Note: The two-tailed $t$-statistics are provided: $* * *$ and $* * *$ represent the respective significance at the 10,5 and 1 per cent levels. "Stand. $\beta$ " stands for standardised beta coefficients.

insurance policies played no major role in consumer decisions. However, when stock markets regained momentum, from 2004 until the beginning of the last financial crisis in 2008 , the decision on which insurer to choose for life insurance is again influenced by the total return offered. This effect can be interpreted such that during crises, consumers value the overall safety effect of life insurance more greatly (guarantees, regulated investment strategies, no risk of loss due to the nationwide protection system, etc.) and do not focus on pure prospects of return. However, when stock markets are doing well and returns can be achieved otherwise than through investment in more conservative life products, the performance becomes an important sales argument. This trend seems also to be confirmed in the period following the last financial crisis, starting from 2009 (see regression model R4). In this subsample, the return even has a negative impact on overall sales success. In fact, a high level of firm returns during crisis periods can symbolise that insurers have high risks, and consumers thus respond negatively to an increase in firm returns during the market downturn. Solvency level $S O$ and company size $S I$ are no longer significant which may be explained by the small data set. The adjusted $R^{2}$ of the model is 0.385 . Nevertheless, the results of regression model (R4) should be interpreted with caution. The analysis is only based on a three-year sample. Finally, let us recall that through all models the level of acquisition costs $A C$ (in other words, commissions to salesforce) and a company's rating $R A$ have the highest impact on the sales success.

\section{Extension of the results to include customer preferences (models $R 5$ and R6)}

Let us now turn to the two remaining regression models on the basis of our reference case. In model (R5), we include the control variable customer satisfaction $S A$. The results are reported in Table 8.

In contrast to the results obtained for reference model (R1), as shown in Table 6, company size $S I$ and solvency level $S O$ no longer appear to be significant drivers in this regression model (R5). However, the other previously significant control variables maintain their explanatory power. In addition, customer satisfaction $S A$ gets significant explanatory power at the 5 per cent level. However, the sign of the estimate is negative. Contrary to our initial 
Table 8 Empirical results of regression model (R5) on sales success in German life insurance including the control variable customer satisfaction $S A$

\begin{tabular}{lrrrrr}
\hline Variables & Est. $\left(\beta_{i}\right)$ & St. error & p-value & Sig. & Stand. $\beta_{i}$ \\
\hline$\alpha$ & 0.1007 & 0.0788 & 0.2028 & & \\
$R E$ & 1.4640 & 0.6021 & 0.0159 & $* *$ & 0.1670 \\
$A C$ & 0.4985 & 0.0563 & 0.0000 & $* * *$ & 0.6213 \\
$R A$ & 0.0077 & 0.0033 & 0.0227 & $* *$ & 0.1995 \\
$S O$ & 0.0784 & 0.1635 & 0.6319 & & 0.0295 \\
$S I$ & -0.0000 & 0.0000 & 0.4108 & -0.0509 \\
$S S$ & 0.0094 & 0.0071 & 0.1870 & $* *$ & 0.0823 \\
$S A$ & -0.0536 & 0.0269 & 0.0481 & -0.1399
\end{tabular}

Adjusted $R^{2} \quad 0.3274$

Note: The two-tailed $t$-statistics are provided: $* * *$ and $* * *$ represent the respective significance at the 10,5 and 1 per cent levels. "Stand. $\beta_{i}$ " stands for standardised beta coefficients.

hypothesis (H7), customer satisfaction $S A$ has a negative impact on sales success. Given that the underlying data sample shrank to less than one-fourth of the original panel with now $N=202$ data points of firm-years, further research could address this topic again when more data points become available. Moreover, additional analysis could verify whether the measures provided by YouGov adequately capture customer satisfaction in the present context. $^{64}$

In addition, we conducted a variation of the reference case with another consumer-related control variable, the value of brand awareness $B A$. This last model at the business unit level represents model (R6). Our empirical results show no significant influence on new business generation. Thus, hypothesis (H8) could not be empirically verified. Apart from company size $S I$ (which is no longer significant), all other control variables maintain their significance levels from the reference case. The adjusted $R^{2}$ of the model is 0.467 . As was true for model (R5), we must point out that our analysis was based on a smaller subpanel (see also Table 3). Therefore, these results should be interpreted with caution.

\section{Product-specific growth drivers}

After having discussed the impact of different drivers on the overall ability of insurance companies to generate new business in life insurance, we now focus on two specific products: pension and term life insurance. As described above, we apply two more regression models to do this. Model (R7) addresses the growth drivers in pension insurance, and (R8) analyses the determinants of new business generation for term life insurance. The results are presented below.

\section{Model (R7): Specific drivers in pension insurance}

For the performance of underwriting new pension business, we adapt the total return $R E$ figures from the product average (as stated in the section "Data set definition and

\footnotetext{
${ }^{64}$ See also the discussion in Assekurata (2006a).
} 
Table 9 Empirical results of regression model (R7) on sales success in pension insurance

\begin{tabular}{lrrrrr}
\hline Variables & Est. $\left(\beta_{i}\right)$ & St. error & $p$-value & Sig. & Stand. $\beta_{i}$ \\
\hline$\alpha$ & -0.1207 & 0.0969 & 0.2160 & & \\
$R E_{P E}$ & 3.8185 & 2.0240 & 0.0624 & $*$ & 0.2249 \\
$A C$ & 0.4675 & 0.1145 & 0.0001 & $* * *$ & 0.3777 \\
$R A$ & 0.0121 & 0.0058 & 0.0404 & $* *$ & 0.2311 \\
$S O$ & 1.8249 & 0.5608 & 0.0016 & $* * *$ & 0.3062 \\
$S I$ & 0.0000 & 0.0000 & 0.7820 & & 0.0258 \\
$L S$ & -0.0008 & 0.0121 & 0.9491 & & -0.0063 \\
$O T_{P E}$ & -0.0051 & 0.0051 & 0.3214 & & -0.1050
\end{tabular}

Adjusted $R^{2}$

0.3147

Note: The two-tailed $t$-statistics are provided: $* * *$ and $* * *$ represent the respective significance at the 10,5 and 1 per cent levels. "Stand. $\beta_{i}$ " stands for standardised beta coefficients.

statistics") to the average of the pension-specific ones (denoted by $R E_{P E}$ ), that is, the average for traditional pension policies, the "Riester-Rente" and "Ruerup-Rente". The results of the multivariate regression model (R7) based on $N=123$ firm-years are presented in Table 9. ${ }^{65}$

This seventh regression models explains about 31 per cent of the variance (adjusted $R^{2}$ of 0.3147). The control variables total return $R E_{P E}$, acquisition costs $A C$, company rating $R A$ and solvency level $S O$ remain significant drivers for selling pension insurance. All have relevant positive influence (in line with the hypothesis stated in the section "Model framework and data set"). When looking at the standardised beta coefficients, the magnitude of their influence is relatively comparable with standardised beta coefficients ranging from 0.22 to 0.38 , respectively. However, it should be noted that the assessment by Oekotest parameterised using the product rating $O T_{P E}$ has no significant explanation power. Hypothesis (H9) in the section "Data set definition and statistics" cannot be verified. Recall that the regression is based on a much smaller sample size, which is restrained by limited data availability, with a total of $N=123$ data points.

\section{Model (R8): Specific drivers in term life insurance}

In the last regression model (R8), we analyse the determinants of new business generation in term life insurance. Securing the financial stability of the bereaved-especially for families - in the case of death, this product achieved new sales volumes of 690,000 policies across Germany in 2011 (Table 35) ${ }^{4}$. Table 10 shows the results of the regression model concerning sales success in term life insurance on the basis of $N=122$ firm-years.

None of the previously significant control variables has any more explanatory power in this model. It is not surprising that, for example, acquisition costs $A C$ are no longer a significant driver, as the commission which sales personnel receive for this product is negligible in comparison to the commission for pension insurance. However, it is surprising that solvency level $S O$ and company rating $R A$ seem to have no relevant impact on the

65 On this subpanel of data, we have also tested the variance inflation factors. The highest value is 2.0 and thus multi-collinearity can be omitted. 
Table 10 Empricial results of regression model (R8) on sales success in term life insurance

\begin{tabular}{lrrrrr}
\hline Variables & Est. $\left(\beta_{i}\right)$ & St. error & p-value & Sig. & Stand. $\beta_{i}$ \\
\hline$\alpha$ & 0.2233 & 0.0533 & 0.0001 & $* * *$ & -0.0895 \\
$A C$ & -0.1580 & 0.1841 & 0.3926 & & -0.0152 \\
$R A$ & -0.0012 & 0.0081 & 0.8849 & 0.0472 \\
$S O$ & 0.3126 & 0.6409 & 0.6267 & -0.0302 \\
$S I$ & -0.0000 & 0.0000 & 0.7548 & -0.1011 \\
$L S$ & -0.0214 & 0.0203 & 0.2955 & -0.1196 \\
$O T_{T L}$ & -0.0109 & 0.0097 & 0.2672 & & -0.1693 \\
$P R_{T L}$ & -0.0000 & 0.0000 & 0.0794 & $*$ &
\end{tabular}

Adjusted $R^{2} \quad 0.01353$

Note: The two-tailed $t$-statistics are provided: $* * *$ and $* * *$ represent the respective significance at the 10,5 and 1 per cent levels. "Stand. $\beta_{i}$ " stands for standardised beta coefficients.

customer's purchasing decision. On the one hand, this may be partly explained by the fact that policyholders are protected against the insolvency of their insurer through the industry's guaranty fund. On the other hand, policyholders may not care about rating, solvency and size because term life insurance contracts entail no endowment part. In addition, it may also be that competition drives life insurers to offer term life products that have similar guaranteed interests and profit participations. The same low significancy applies for the control variable parameterising the Oekotest product assessment $O T_{T L}$. Finally, the average price $P R_{T L}$ is significant at the 10 per cent level with a negative sign, which supports hypothesis (H10). In the end, note that this model has only an extremely modest overall explanatory power of 0.014 .

\section{Conclusion}

The landscape in the German life insurance market is currently driven by two trends. On the one hand, the number of active insurance companies is decreasing and the market is consolidating. On the other hand, the large remaining players are steadily increasing their market share. While the five largest life insurers had a market share of 31 per cent in terms of gross written premiums in 1998, this group increased its share to 39 per cent in 2011 . More than half of the industry's premiums were collected by the ten largest firms in 2011. Insurers must grow to avoid falling behind the industry leaders and thus ensure solid market positioning in the future.

In an initial discussion, we analyse the impact of size on growth and profitability in a time period covering the years from 1998 to 2011. Three main effects can be observed: first, midsized insurers are subject to the typical "stuck-in-the-middle" phenomenon: their growth and profitability development is modest. Second, small insurers have been able to achieve high growth rates in the past. Initially realised at the expense of profitability, following the last financial crisis, the smallest players experienced a turn-around in terms of profitability and continued to grow more slowly but profitably during the time period from 2009 to 2011 . 
Finally, the data show that the largest companies were able to achieve both satisfying growth rates and profitability during all observed time periods. The analysis reveals that profitable growth has been possible in German life insurance in the past.

In the main part of this paper, we focus on the success drivers for new business growth and thus build on the findings by Eling and Kiesenbauer. ${ }^{8}$ Following a twofold approach, we analyse the impact of different control variables both on the overall life business and on a product-specific level. Our analysis reveals that acquisition costs, which mainly represent commissions to sales partners, have a strong positive impact on sales success. Not surprisingly, the empirical data also confirm that the total return that an insurer generates for its policyholders is crucial. In addition, the rating of the company and its solvency fosters new business generation. Furthermore, contrary to our initial hypothesis, customer satisfaction has a slightly negative impact. At the pension insurance product level, most of the significant drivers that have been identified are once again important. In addition, the available panel data reveal that — contrary to our initial hypothesis-the product assessment reports by consumer magazines have no measurable significant influence on the sales performance of a life insurer. Further research could deepen our analysis at the product level. Since product-specific ratings are only available for recent years, the data basis is limited. In the future, an analysis could be conducted using more data points and thus increase the stability of the results for specific product growth drivers.

Following our findings, insights regarding the strategy of German life insurers on expanding business can be derived. Given the current discussion about the future of life insurance in general due to the low interest-rate environment, firms must focus on the relevant levers to achieve growth in this difficult market environment. Our analysis shows the importance of adequate acquisition costs. As easy this as a lever sounds, in order to achieve growth, many insurers are currently focusing on cost efficiency and also target sales expenses in their cost reduction programmes. At least, insurers could rethink the area where to specifically reduce distribution costs. In addition, the relevance of sustainable brand positioning in ratings combined with a solid risk management to keep solvency levels high seems to have an advantageous effect for growth. Although our analysis is not fully comprehensive, the paper contributes to understanding the dynamics of an industry which is in the middle of a paradigm shift.

\section{References}

Adams, M.B. and Tower, G.D. (1994) 'Theories of regulation: Some reflections on the statutory supervision of insurance companies in Anglo-American countries', The Geneva Papers on Risk and Insurance-Issues and Practice 19(71): 156-177.

Anderson, E.W., Fornell, C. and Lehmann, D.R. (1994) 'Customer satisfaction, market and profitability: Findings from', Journal of Marketing 58(3): 53-66.

Assekurata (2005) Die Überschussbeteiligung in der Lebensversicherung 2005. Anhang B: Deklarationssätze der Lebensversicherer und Kommentare, from www.assekurata.de, accessed 10 September 2012.

Assekurata (2006a) Die Bedeutung von Ratings für den deutschen Versicherungsmarkt, from www.assekurata.de.

Assekurata (2006b) Die Überschussbeteiligung in der Lebensversicherung 2006. Anhang B: Deklarationssätze der Lebensversicherer und Kommentare, from www.assekurata.de, accessed 10 September 2012.

Assekurata (2007) Die Überschussbeteiligung in der Lebensversicherung 2007. Anhang B: Deklarationssätze der Lebensversicherer und Kommentare, from www.assekurata.de, accessed 10 September 2012. 
Assekurata (2008) Die Überschussbeteiligung in der Lebensversicheurng 2008. Anhang B: Deklarationssätze der Lebensversicherer und Kommentare, from www.assekurata.de, accessed 10 September 2012.

Assekurata (2009) Die Überschussbeteiligung in der Lebensversicherung 2009. Anhang B: Deklarationssätze der Lebensversicherer und Kommentare, from www.assekurata.de, accessed 10 September 2012.

Assekurata (2010) Die Überschussbeteiligung in der Lebensversicherung 2010. Anhang B: Deklarationssätze der Lebensversicherer und Kommentare, from www.assekurata.de, accessed 10 September 2012.

Assekurata (2011) Die Überschussbeteiligung in der Lebensversicherung 2011. Anhang B: Deklarationssätze der Lebensversicherer und Kommentare, from www.assekurata.de, accessed 10 September 2012.

Berry-Stölzle, T.R. and Born, P. (2012) 'The effect of regulation on insurance pricing: The case of Germany', The Journal of Risk and Insurance 79(1): 129-164.

Berry-Stölzle, T.R., Liebenberg, A.P., Ruhland, J.S. and Sommer, D.W. (2012) 'Determinants of corporate diversification: Evidence from the property-liability insurance industry', The Journal of Risk and Insurance 79(2): 381-413.

Bonin, H. (2009) '15 years of pension reform in Germany: Old successes and new threats', The Geneva Papers on Risk and Insurance-Issues and Practice 34(4): 548-560.

Brockett, P.L., Cooper, W.W., Golden, L.L., Rousseau, J.J. and Wang, Y. (2005) 'Financial intermediary versus production approach to efficiency of marketing distribution systems and organizational structure of insurance companies', The Journal of Risk and Insurance 72(3): 393-412.

Brown, J.R. and Goolsbee, A. (2002) 'Does the Internet make markets more competitive? Evidence from the life insurance industry', Journal of Political Economy 110(3): 481-507.

Browne, M.T. and Kim, K. (1993) 'An international analysis of life insurance demand', The Journal of Risk and Insurance 60(4): 616-634.

Campbell, R.A. (1980) 'The demand for life insurance: An application of the economics of uncertainty', The Journal of Finance 35(5): 1155-1172.

Chen, M.-J. and Hambrick, D.C. (1995) 'Speed, stealth, and selective attack: How small firms differ from large firms in competitive behavior', The Academy of Management Journal 38(2): 453-482.

Chen, R., Wong, K.A. and Lee, H.C. (2001) 'Age, period, and cohort effects on life insurance purchases in the U.S.', The Journal of Risk and Insurance 68(2): 303-327.

Choi, J.J., Laibson, D. and Madrian, B.C. (2010) 'Why does the law of one price fail? An experiment on index mutual funds', The Review of Financial Studies 23(4): 1405-1432.

Cottin, C., Heinke, V., Homann, W. and Sander, C. (2007) 'Empirische analyse des Einflusses der Überschussbeteiligung auf Neugeschäft und Storno', Zeitschrift für die gesamte Versicherungswissenschaft 96(3): 339-373.

Cummins, J.D., Weiss, M.A. and Zi, H. (1999) 'Organizational form and efficiency: The coexistence of stock and mutual property-liability insurers', Management Science 45(9): 1254-1269.

De Maeyer, P. and Estelami, H. (2011) 'Consumer perceptions of third party product quality ratings', Journal of Business Research 64(10): 1067-1073.

Dwyer, S., Hill, J. and Martin, W. (2000) 'An empirical investigation of critical success factors in the personal selling process for homogenous goods', Journal of Personal Selling \& Sales Management 20(3): 151-159.

Eling, M. and Kiesenbauer, D. (2012) 'Does surplus participation reflect market discipline? An analysis of the German life insurance market', Journal of Financial Services Research 42(3): 159-185.

European Commission (2002) Directive 2002/83/EC of the European Parliament and of the Council of 5 November (2002) concerning life assurance, from eur-lex.europa.eu.

European Commission (2009) Directive 2009/138/EC of the European Parliament and of the Council on the TakingUp and Pursuit of the Business of Insurance and Reinsurance (Solvency II), from eur-lex.europa.eu.

European Union (1992) Council Directive 92/96/EEC of the European Parliament and of the Council, Official Journal of European Communities.

European Union (2002) Directive 2002/13/EC of the European Parliament and of the Council, Official Journal of the European Communities, vol. 45.

Fiegenbaum, A. and Thomas, H. (1990) 'Strategic groups and performance: The U.S. insurance industry 1970-84', Strategic Management Journal 11(3): 197-215.

GDV (2012) Statistisches Taschenbuch der Versicherungswirtschaft 2012, technical report.

German Federal Ministry of Justice (2008) Verordnung über die Mindestbeitragsrückerstattung in der Lebensversicherung (MindZV).

German Federal Ministry of Justice (2011) Verordnung über Rechnungsgrundlagen für die Deckungsrückstellungen (DeckRV). 
Handelsblatt (2011, 7 October) Wie lässt sich die Rentenlücke am besten schließen?

Hardwick, P. and Adams, M. (2002) 'Firm size and growth in the United Kingdom life insurance industry', The Journal of Risk and Insurance 69(4): 577-593.

Klein, R.W. (1995) 'Insurance regulation in transition', The Journal of Risk and Insurance 62(3): 363-404.

Klumpes, P.J.M. and Schuermann, S. (2011) 'Corporate, product and distribution strategies in the European life insurance industry', The Geneva Papers on Risk and Insurance-Issues and Practice 36(1): 50-75.

Kozup, J., Howlett, E. and Pagano, M. (2008) 'The effects of summary information on consumer perceptions of mutual fund characteristics', The Journal of Consumer Affairs 42(1): 37-60.

Lewis, F.D. (1989) 'Dependents and the demand for life insurance', The American Economic Review 79(3): $452-467$.

Li, D., Moshirian, F., Nguyen, P. and Wee, T. (2007) 'The demand for life insurance in OECD countries', The Journal of Risk and Insurance 74(3): 637-652.

Liebenberg, A.P. and Sommer, D.W. (2008) 'Effects of corporate diversification: Evidence from the property liability insurance', The Journal of Risk and Insurance 75(4): 893-919.

Longenecker, C.O., Simonetti, J.L. and Sharkey, T.W. (1999) 'Why organizations fail: The view from the front-line', Management Decision 37(6): 503-513.

Luo, X., Homburg, C. and Wieseke, J. (2010) 'Customer satisfaction, analyst stock recommendations, and firm value', Journal of Marketing Research 47(6): 1041-1058.

Mantis, G. and Farmer, R.N. (1968) 'Demand for life insurance', The Journal of Risk and Insurance 35(2): 247-256.

Map-Report (2005) Nr. 590. Deklarationssätze 2005 und Schlussverkaufsbilanz, from www.map-report.de, accessed 27 October 2012.

Map-Report (2012) Nr. 811-813. Bilanzanalyse Deutscher Lebensversicherer 2011, from www.map-report.de, accessed 27 October 2012.

Milbrodt, H. and Helbig, M. (1999) Mathematische Methoden der Personenversicherung, Berlin, New York: Walter de Gruyter.

Mooradian, T.A. and Olver, J.M. (1997) “"I can't get no satisfaction”: The impact of personality and emotion on postpurchase processes', Psychology \& Marketing 14(4): 379-393.

Nektarios, M. (2010) 'Deregulation, insurance supervision and guaranty funds', The Geneva Papers on Risk and Insurance-Issues and Practice 35(3): 452-468.

Oekotest (2007a) 'Der Vorsorge-Klassiker', Oekotest 9: 168-199.

Oekotest (2007b) 'Für den schlimmsten Fall', Oekotest 12: 176-186.

Oekotest (2008a) 'Für den schlimmsten Fall', Oekotest 7: 142-149.

Oekotest (2008b) 'Kostenwirrwarr', Oekotest 7: 140-159.

Oekotest (2009) 'Reinfall statt Rendite', Oekotest 7: 26-69.

Oekotest (2010) 'Vorsorge für den schlimmsten Fall', Oekotest 10: 124-135.

Oekotest (2011) 'Reise ins Labyrinth', Oekotest 6: 86-101.

Porter, M. (1985) Competitive Advantage. Creating and Sustaining Superior Performance, New York: The Free Press.

Sirri, E.R. and Tufano, P. (1998) 'Costly search and mutual fund flows', The Journal of Finance 53(5): 1589-1622.

Spiller, R. (1972) 'Ownership and performance: Stock and mutual life insurance companies', The Journal of Risk and Insurance 39(1): 17-25.

Statistisches Bundesamt (2012) Einwohnerzahl Deutschlands im Jahr 2011 erstmals seit 2002 wieder gestiegen, from http://www.destatis.de, accessed 2 November 2012.

Stern (2003) MarkenProfile 10, from shop.stern.de, accessed 27 October 2012.

Stern (2005) MarkenProfile 11, from shop.stern.de, accessed 27 October 2012.

Stern (2008) MarkenProfile 12, from shop.stern.de, accessed 27 October 2012.

Tekülve, V. (2007) Die Bedeutung der Überschussbeteiligung für die Neugeschäftsentwicklung des Lebensversicherungsgeschäfts, Frankfurt a. M: Fritz Knapp Verlag.

Varaiya, N., Kerin, R.A. and Weeks, D. (1987) 'The relationship between growth, profitability, and firm value', Strategic Management Journal 8(5): 487-497.

Vogel, V., Evanschitzky, H. and Ramaseshan, B. (2008) 'Customer equity drivers and future', Journal of Marketing 72(6): 98-108.

Wakker, P.P., Thaler, R.H. and Tversky, A. (1997) 'Probabilistic insurance', Journal of Risk and Uncertainty 15(1): $7-28$. 
Wilcox, R.T. (2003) 'Bargain hunting or star gazing? Investors' preferences for stock mutual funds', Journal of Business 76(4): 645-663.

Wirtschaftswoche (1999) 'Keine leichte Entscheidung', Wirtschaftswoche 47: 222.

Wirtschaftswoche (2000) 'Speck ansetzen', Wirtschaftswoche 45: 342.

Wirtschaftswoche (2001) 'Stark abfedern', Wirtschaftswoche 49: 169.

Wirtschaftswoche (2002) 'Land in Sicht', Wirtschaftswoche 44: 160.

Wirtschaftswoche (2003) 'Offene Arme', Wirtschaftswoche 43: 141.

Wirtschaftswoche (2004) 'Im Winterschlussverkauf', Wirtschaftswoche 47: 158.

Wirtschaftswoche (2005) 'Gegenwind', Wirtschaftswoche 46: 140.

Wirtschaftswoche (2006) 'Mehr Schlagkraft', Wirtschaftswoche 46: 148.

Wirtschaftswoche (2007a) 'Peer und Brigitte', Wirtschaftswoche 47: 164.

Wirtschaftswoche (2007b) 'Schade, dass Sie nicht alt sind! Wie alt können Sie sich leisten? Alles, was Sie jetzt über Altersvorsorge wissen müssen', Wirtschaftswoche 47: 160.

Wirtschaftswoche (2008) 'Der wahre Stresstest', Wirtschaftswoche 45: 138.

Wirtschaftswoche (2009) 'Halbe Portion', Wirtschaftswoche 49: 110.

Wirtschaftswoche (2010) 'Nur die Besten wachsen in den Himmel', Wirtschaftswoche 45: 140.

Wirtschaftswoche (2011) 'Dem Sturm standhalten', Wirtschaftswoche 47: 112.

YouGov (2003) Kundenmonitor Assekuranz, 2003. Technical Report.

YouGov (2008) Kundenmonitor Assekuranz, 2008. Technical Report.

YouGov (2010) Kundenmonitor Assekuranz 2010. Technical Report.

Zimmer, A., Schade, C. and Gründl, H. (2009) 'Is default risk acceptable when purchasing insurance? Experimental evidence for different probability representations, reasons for default, and framings', Journal of Economic Psychology 30(1): 11-23.

Zimmermann, J. (1996) Wertmessung und Erfolgssteuerung in Lebensversicherungsunternehmen, Karlsruhe: Verlag Versicherungswirtschaft.

\section{About the Authors}

Jonas Lorson holds the degree of Master of Science. He studied General Management at the European Business School (EBS), Oestrich-Winkel (Germany). He also holds a PhD from the Institute of Insurance Economics at the University of St. Gallen (Switzerland). Currently, he is working at the Boston Consulting Group and focuses on insurance topics. His main research interest includes life insurance and securitisation.

Joël Wagner is an Assistant Professor of Risk Management and Insurance at the University of St. Gallen and Member of the Executive Board of the Institute of Insurance Economics. Before he was a consultant in the Financial Services and Insurance practice of the Boston Consulting Group. He holds a venia legendi in Business Administration with special emphasis on Risk Management from the University of St. Gallen, and a PhD in Mathematics and an engineering degree in Physics from the Swiss Federal Institute of Technology in Lausanne. 